\title{
EARLY BYZANTINE RESIDENTIAL ARCHITECTURE IN JIYEH (PORPHYREON) AFTER EXCAVATION SEASONS IN 2012 AND 2013
}

\begin{abstract}
This article presents the results of current studies of Early Byzantine residential architecture in Jiyeh (ancient Porphyreon) that represents the best preserved remains of architecture of this period on the Lebanese coast. This preliminary characteristic is based on fieldwork carried out in 2012-13 in the northern, southeastern and western parts of the important housing quarter in Sector D, extended to include the investigations in Sector E in 2013. The discussion draws upon the results of earlier excavation work in Jiyeh (Porphyreon), also taking into account parallels from other Syro-Palestinian sites.
\end{abstract}

\section{INTRODUCTION}

The well preserved housing quarter in Jiyeh, the site of ancient Porphyreon on the Lebanese coast, holds substantial potential for studies of the continuity and transformation of the local building tradition in Early Byzantine times. It is also a source of information on social organization and development of residential areas of mixed urban and rural character, combining functions as centers of agriculture, craft and trade. ${ }^{1}$ The residential quarter was first explored in 1975 by a Lebanese team from the Direction Générale des Antiquités led by R. Saidah. The dig was interrupted by the outbreak of the civil war in Lebanon and the results have never been published, but a brief report presented in 1977 demonstrated the extent of the explored district (almost 1000 sq.m) and its state of preservation with walls rising up to $2 \mathrm{~m}$ in places. ${ }^{2}$

A new phase in the research started in 2008 when a team from the Polish Centre of Mediterranean Archaeology of the University of Warsaw embarked on a program of cleaning and documenting residential

1 More on the history and excavation of the site, see GWIAZDA 2014; WALISZEWSKI, GWIAZDA 2015; WALISZEWSKI, WICENCIAK 2015.

2 SAIDAH 1977. architecture of this quarter, providing an opportunity for a reassessment of the original discovery and a study of the new findings. The present article reports on fieldwork carried out in 2012 and 2013, supplemented with observations made in $2008-10,{ }^{3}$ supplying data for a preliminary characteristic of Early Byzantine residential architecture in Jiyeh. A discussion of the form, function and chronology of the Early Byzantine houses from Sector D, based on this analysis, constitutes the second part of this article.

The research during the 2012 and 2013 seasons aimed, on one hand, to test a stratigraphic sequence underlying the Early Byzantine quarter and, on the other hand, to study the latest, best preserved settlement level in the village. ${ }^{4}$ The remains once excavated by R. Saidah were cleared and verified, supplemented with an inventory of standing architectural features. ${ }^{5}$ Excavations concentrated on three different parts of the habitation quarter in Sector D: southeastern (areas D42, D87-D89, D111-D115), western (trench T5) and northern (trench T2) (Figs. 1 and 2), the objective being to extend the field of architectural study and interpretation. Local building

\footnotetext{
3 WALISZEWSKI, JUCHNIEWICZ, GWIAZDA 2012; WALISZEWSKI, GWIAZDA 2013.

4 See WALISZEWSKI et al. 2015.

5 SAIDAH 1977.
} 


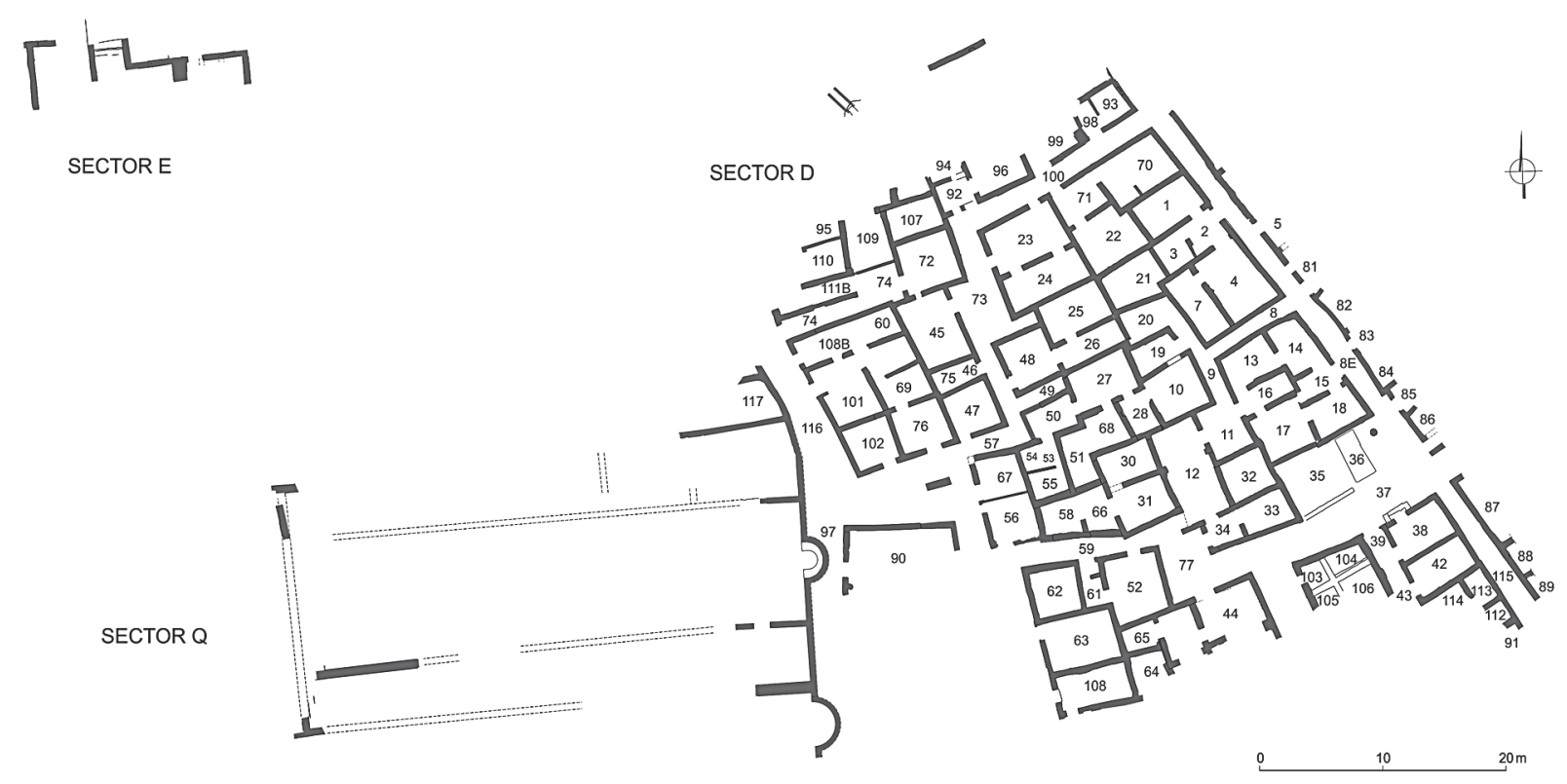

Fig. 1. Plan of the southern part of ancient Jiyeh (drawing M. Puszkarski)

investment (sewage network and pumping station) in the southwestern corner of the area under license to Polish archaeologists necessitated archaeological supervision of trenches, whereas cleaning took place in Sector $\mathrm{E}$ to the northwest, in a plot belonging to the Ministry of Transport where a large storied structure damaged in modern times had been identified. Of greatest importance is a large house with a mosaic floor depicting a lion and wall paintings preserved on the walls. Detailed documentation was carried out in previously explored parts of Sector D as well as in an Early Byzantine wine press discovered near the ancient necropolis during the architectural development of a local tourist resort. ${ }^{6}$

\section{EXCAVATIONS IN SECTORS D AND E}

\section{SECTOR D: SOUTHEASTERN PART ${ }^{7}$}

Preliminary work conducted in 2010 in the area to the south of the eastern part of street D37 (Fig. 3) aimed at clearing the parts of the site previously excavated by R. Saidah: room D38 and the northern part of street D115, and from the west, close to room $\mathrm{D} 43 .{ }^{8} \mathrm{New}$ excavations were carried out in four rooms west of street D115, clearing away up to $1.70 \mathrm{~m}$ of mixed accumulations (building rubble and

6 For this work, see DZIK 2015; KOWARSKA, LENARCZYK 2015.

7 Excavations in this part of the site were supervised by M. Romaniuk and A. Romaniuk.

8 On previous excavations in this part of the site, see WALISZEWSKI, GWIAZDA 2013: 327-328. crumbling lime mortar, sand, and a small number of modern objects).

Room D42 (on the southern side of D38) was of a slightly trapezoid plan, with an entrance from the west and a simple mosaic of big white limestone tesserae running along the diagonal, framed by a border of three rows of tesserae parallel along the walls and around a stone basin in the southwestern corner of the room, close by the threshold. The basin, which was made of blocks of sand conglomerate, was sunk into the floor to a depth of $0.11-0.15 \mathrm{~m}$; it measured $0.46 \times 0.34-0.39 \mathrm{~m}$ and the top edges were at the same level as the floor surface. The bottom was laid with lime mortar with amphora body sherds set in it, their outside surfaces facing up. In the middle of the north wall was a niche with a triangular top. The south, bearing wall was constructed in a headerstretcher bond. A deposit of 12 coins provisionally dated to the second half of the 4th century was found inside this wall, on the level of the single preserved course of stones. The room was apparently connected structurally with D38 having the same kind of mosaic floor and walls constructed in the opus isodomum technique, different from the bondwork in use in buildings farther to the south. Access to both rooms was from a corridor on the western side (marked on R. Saidah's plan as D39 and D43), with elements of a stone pavement in its northern part. The east wall of rooms D38 and D42 was shifted a dozen or so centimeters to the west in relation to the eastern face of the east wall of the next rooms to the south (D113, D112, D91), which should probably indicate another building phase.

In this part of the site, farther south, room D111 turned out to be of a similar size as D42, subdivided 


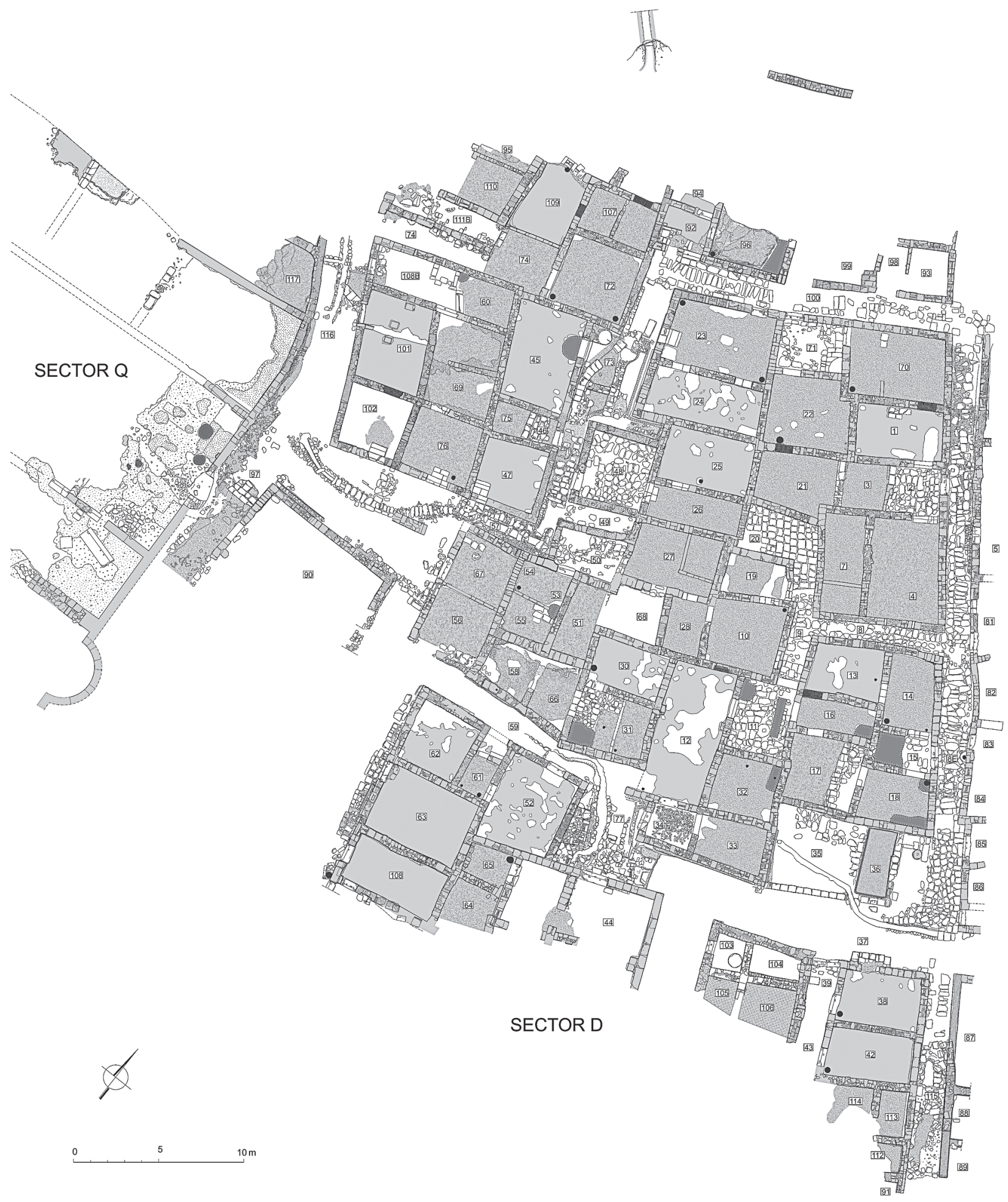

Fig. 2. Plan of Sector D (drawing M. Puszkarski)

at one point by a partition wall running roughly $\mathrm{N}-\mathrm{S}$ between areas D113 and D114. The western and southwestern parts of this room had been destroyed by a robbers' pit. The walls were plastered and the floor was made of lime mortar on a bedding of gravel; the partition wall stood directly on this floor. A new lime mortar floor was introduced in the bigger room on the western side and the walls were all replastered.
A small plastered niche $(0.13 \mathrm{~m}$ high by $0.10 \mathrm{~m}$ wide, $0.13 \mathrm{~m}$ deep) was recorded in the east wall of D113. A ceramic vessel was sunk even with the floor surface in the southeastern corner of the room; it reached down $0.40 \mathrm{~m}$. Farther south was room D112, damaged extensively in its western and central parts by a modern robbers' pit. A deposit of pure lime, $0.60 \mathrm{~m}$ thick and undoubtedly of ancient origin, lay directly on the 


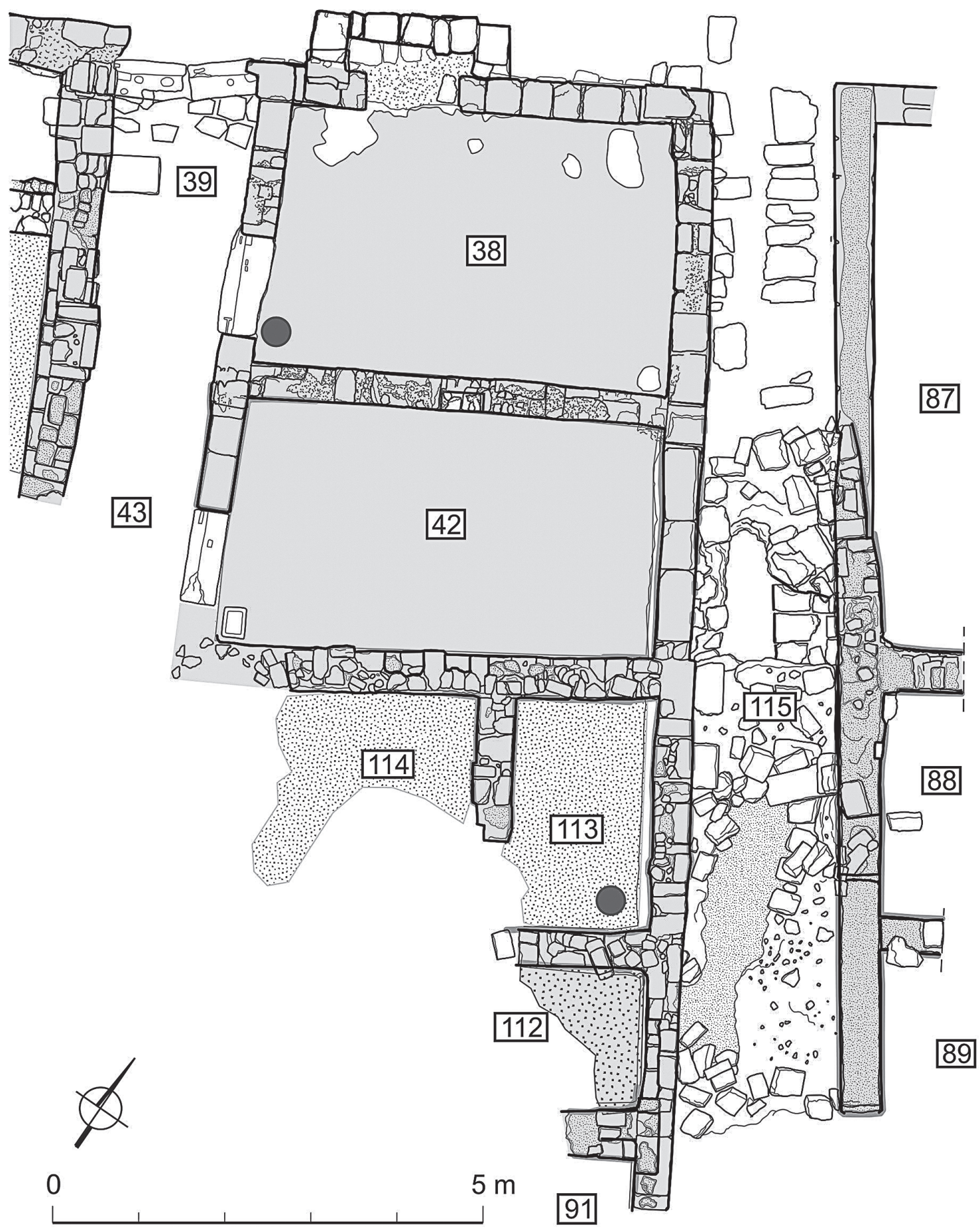

Fig. 3. Plan of the southeastern part of Sector D (drawing M. Puszkarski)

dirt floor in the eastern part. A single bronze coin dated to the 5th century was found in this deposit. Last in this series was room D91, of which only the east wall and a small fragment of the north wall survived. The complex proved to have had a regular rectangular outline and was originally entered from the east side of D112, but in later times this entrance was blocked and plastered. Whether afterwards these rooms were accessed from the west or the south side cannot be determined.

Street D115, bordering the excavated rooms in the east, measured from 1.19 to $1.40 \mathrm{~m}$ in width; it was excavated for a distance of $13 \mathrm{~m}$ (its northern end had been cleared already in 2010) and evidently continued southward. Long limestone slabs paved the walking surface in this passage, covered largely by 


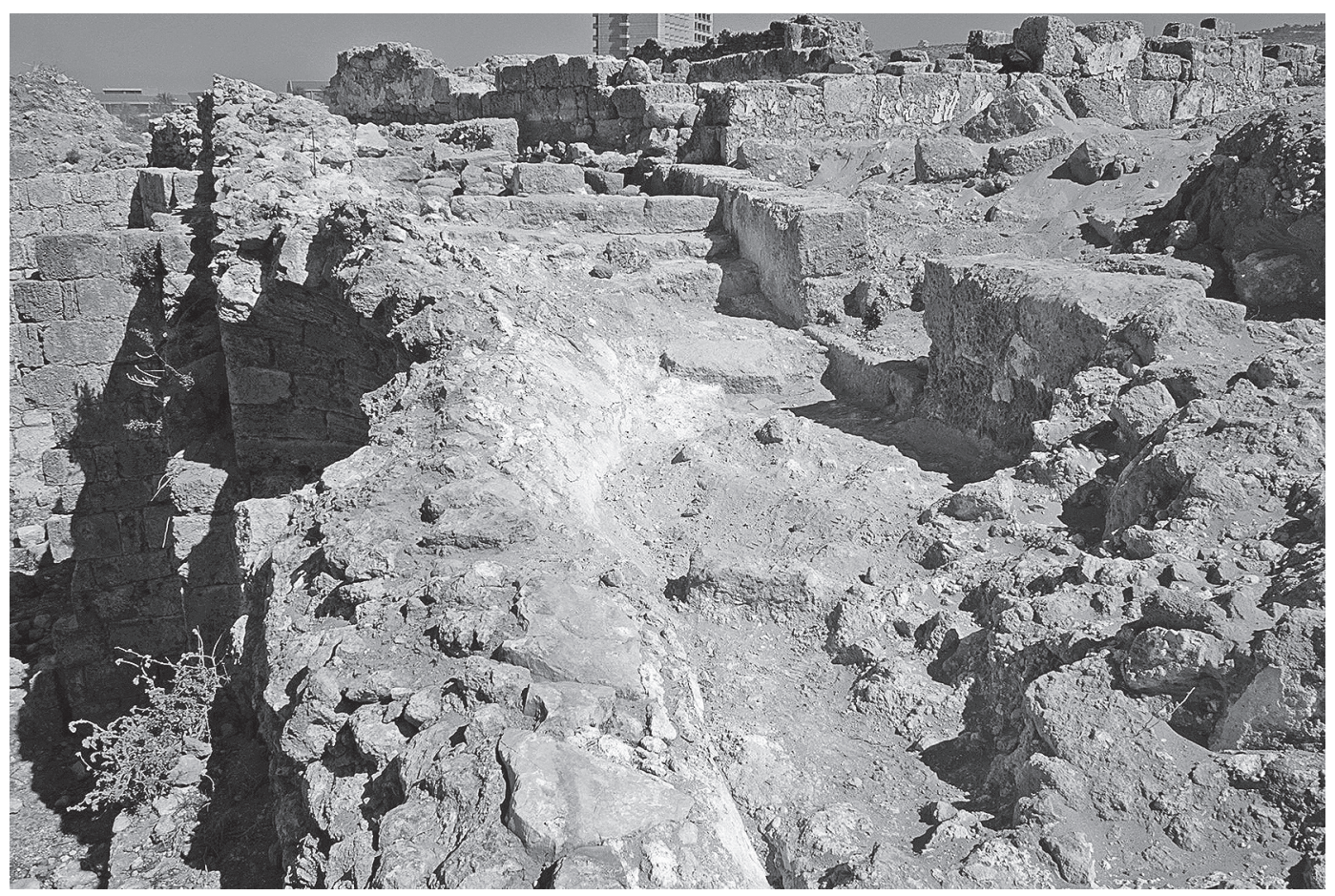

Fig. 4. Trench T5, view from the south (photo R. Bieńkowski)

stone tumble from the walls, either ancient or modern in origin. The rubble was not explored completely. Two partly exposed walls, aligned roughly $\mathrm{E}-\mathrm{W}$, indicated the existence of at least three rooms (D87, D88, D89) to the east of street D115. No door opening from the street was noted anywhere along the length.

\section{SECTOR D: WESTERN PART $\left(\right.$ TRENCH T5 - ROOM D97) ${ }^{9}$}

The trench in the western part of Sector D, at the back of the nave of an Early Byzantine basilica, directly above the conch of its apse, aimed at determining architectural relation at the meeting point of two different quarters (Fig. 4). It was from 2 to $3 \mathrm{~m}$ wide and about $6 \mathrm{~m}$ long, adapting arbitrarily to ground topography in this area. The fill proved entirely modern in origin. Under a layer about $0.50 \mathrm{~m}$ thick was a floor made of lime mortar (area D97), the surface of which was severely destroyed. Three steps led up $0.75 \mathrm{~m}$ into street D116, located to the north and running perpendicularly to the length of the central part of the basilica's east wall (see Fig. 2). The eastern wall of area D97 was destroyed by stone removal save for a section separating this area from the next one to the east (D90 identified in the 2009 season), which proved to have a western entrance, now cleared. The lime mortar floor suggests that at least

9 Excavations in this part of the site were supervised by R. Bienkowski. initially the area D97 was roofed. It could have been a kind of corridor or maybe a continuation of street D116 running alongside the east wall of the basilica.

The steps occupied almost the entire northern side of the trench above the apse, whereas structures related to the basilica were found on the western side. This was a surface tilting to the east found atop the apse of the basilica. ${ }^{10}$ The steps must have followed the building of the basilica. ${ }^{11}$ A provisional terminus ante quem for the lime mortar floor in D97, which preceded the building of the steps, is provided by fine-ware vessels from the beginning of the 7th century. The above mentioned tilted surface, probably meant to discharge water from the basilica roof, was also built after the floor had been laid. Construction in this part of the quarter evidently alternated with different building phases of the basilica.

\section{SECTOR D: NORTHERN PART $\left(\right.$ TRENCH T2) ${ }^{12}$}

The trench cleared part of an area along street D100 excavated earlier by R. Saidah, recognizing seven adjoining rooms arranged along a roughly $\mathrm{E}-\mathrm{W}$ axis

10 Similar structures were noted in the western part of trench T1. See WALISZEWSKI et al. 2015.

11 A terminus ante quem for the construction of the basilica is established by a mosaic inscription from AD 477, see ABOU DIWAN 2014: 153.

12 Excavations in this part of the site were supervised by M. Gwiazda. 


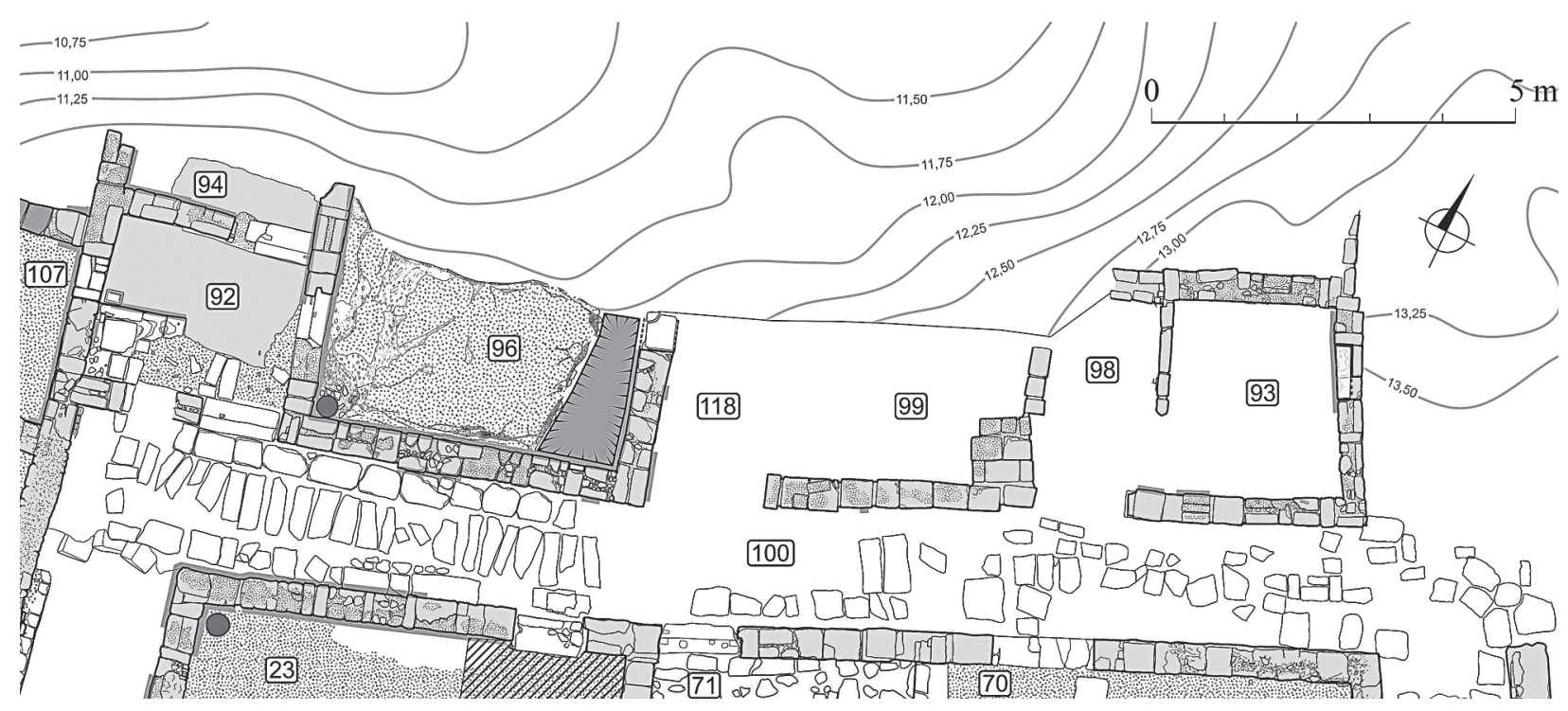

Fig. 5. Plan of structures uncovered in trench T2 (drawing M. Puszkarski)

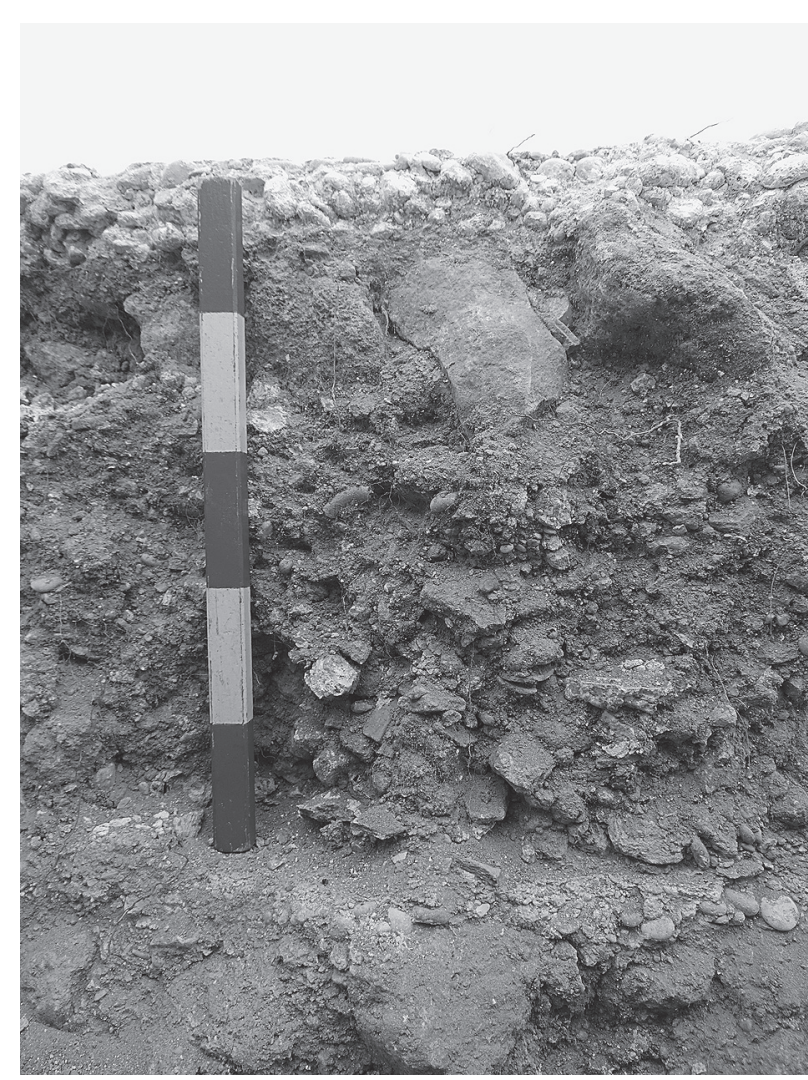

Fig. 6. Older lime mortar floor (scale bar set on it) in the wall of a robbers' pit in room D96 (photo M. Gwiazda)

(Fig. 5). Work in the eastern part of the trench was discontinued once it was determined that the area had not been excavated before and the cleaning shifted to the western end (rooms D92, D94, D96), covered only by modern sand and rubbish deposits. Two of the northernmost rooms had suffered heavy damage due to robbers' pits.
The oldest stratigraphic unit was a floor of lime mortar, located in a robbers' pit in the eastern part of room D96 (Fig. 6). By comparison with stratigraphic sequences noted elsewhere, this level might be attributed to the beginning of the Early Byzantine period. A new lime mortar floor was laid at some point on a leveling layer about $0.30 \mathrm{~m}$ thick and a sunken vessel was installed in the southwestern corner of the newly created room. A rudimentarily preserved plastered niche about $0.20 \mathrm{~m}$ wide appeared in the south wall, the sill located $0.59 \mathrm{~m}$ above floor level. A step by the western entrance negotiated the $0.45 \mathrm{~m}$ difference in levels between the floor and the raised threshold.

A small fragment of a floor made of big white tesserae was uncovered in room D94 that was heavily destroyed in modern times. On the southern side there was a partition wall and a passage, with a partly preserved threshold, that connected this room with D92. Three coats of plaster were noted on the south and east walls. Two of them extended below the mosaic floor level, whereas the latest one came slightly onto the mosaic.

Room D92, smaller than D96, was paved with a mosaic floor made of big white tesserae (Fig. 7). Three structural elements had been put in place in an initial phase of construction prior to the laying of the mosaic: a step to the street, stairs and a stone basin. The partly preserved step made of limestone blocks on the south side of the room negotiated the difference in levels between the floor and the southern entrance from street D100. The staircase occupied the southwestern corner, leading up to a room above D107 at an upper level to the west; it was built of regular blocks of sandstone conglomerate bonded in lime mortar and preserves traces in the mortar of 


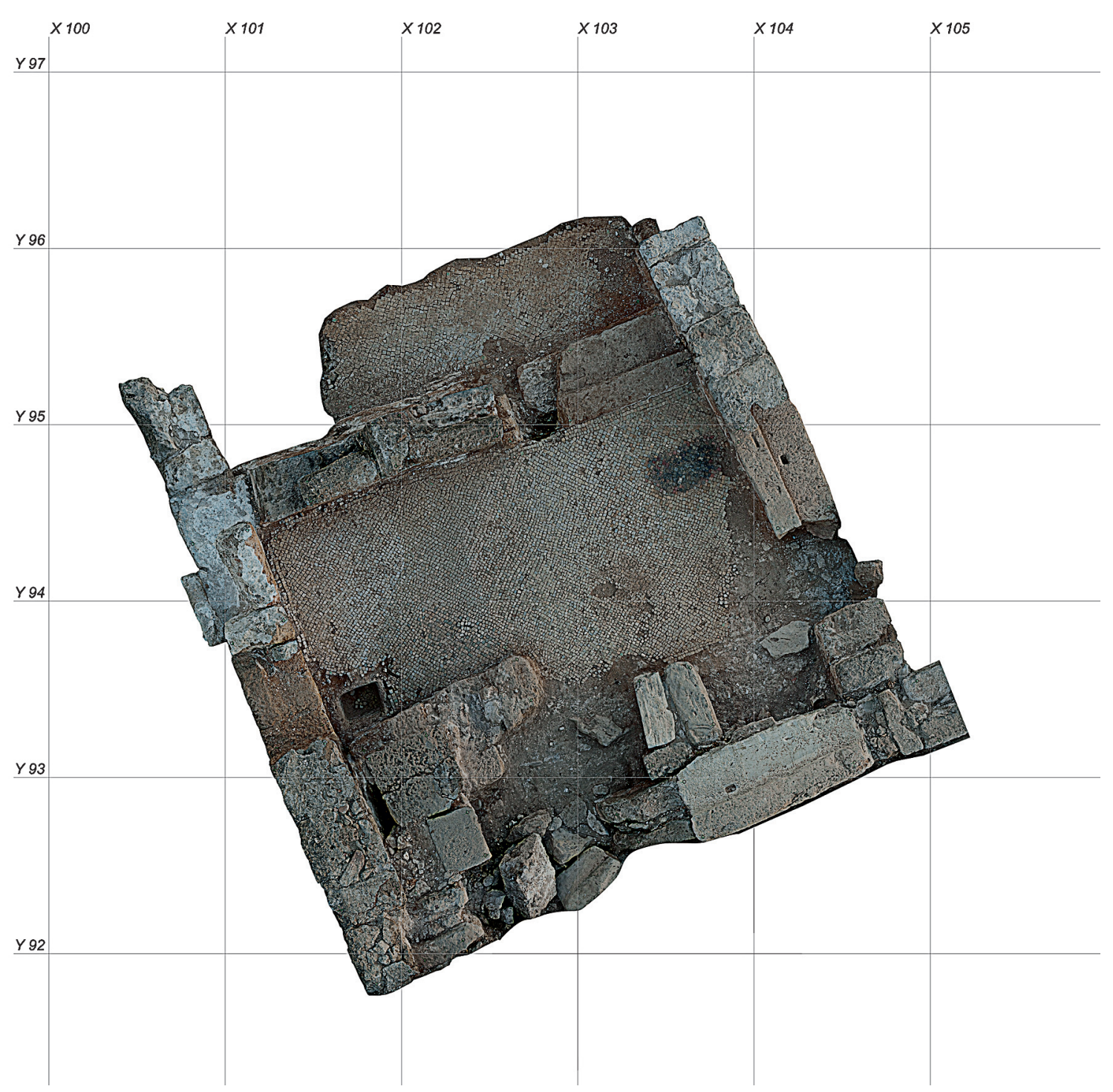

Fig. 7. Top view of room D92 (ortophoto R. Solecki)

a third tread on top of the preserved two. The basin, cut out of an ashlar of sandstone conglomerate, was set into the floor in the western part of the area; it measured 0.33 by $0.26 \mathrm{~m}$ and was $0.16 \mathrm{~m}$ deep. An opening about $0.50 \mathrm{~m}$ wide was pierced later in the west wall, right behind the stone basin, connecting the room to D107 that had both entrances blocked presumably at this time, excluding it from the group of rooms D72, D74, D109, D111B and annexing it to the D92, D94 and D96 group. Wooden stairs or a ladder must have been used to access it due to a significant difference, $1.50 \mathrm{~m}$, in levels between the opening in the west wall of D97 and the floor in D107. Another important feature uncovered near room D92 was a branch of a sewage channel that reached the southern face of the south wall of the room. It was a continuation of the installation located at the western end of street D100. Broken fragments of a ceramic waterspout that had been used for discharg- ing water from the roof of room D92 were found in the fill.

Cleaning of wall tops in the eastern part of the trench, where excavations had not been continued, as explained above, traced four areas. D93 and D98, farthest to the east, were possibly a single room partitioned by a roughly $\mathrm{N}-\mathrm{S}$ wall. Its thickness (just $0.18 \mathrm{~m}$ ) indicated its role as a partition, similarly to walls in rooms D101 and D107, among others. ${ }^{13}$ The negative on the south wall of D107 indicates that the partition of this kind reached no higher than $1.20 \mathrm{~m}$ above floor level. Room D98 was entered from the south, the surviving threshold being roughly level

13 Walls of this type can be observed also between rooms D2 and D3, and in rooms D7, D69, D70, D74. Similar materials and technique were used in rooms D22, D27/27a, D31, which had tanks for lime. In this case, however, the walls were considerably lower. 


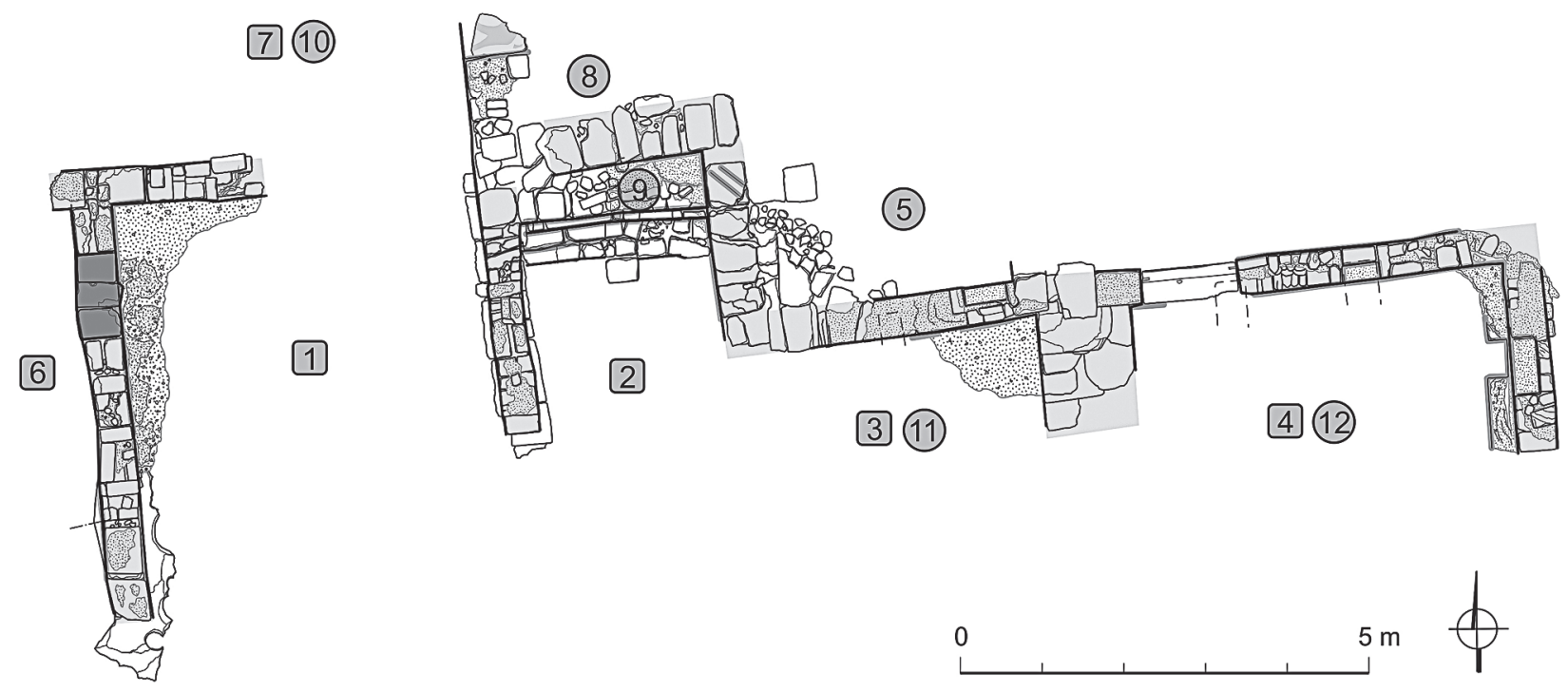

Fig. 8. Sector E: room numbers on the first floor in boxes, those on the upper floor in circles (drawing M. Puszkarski)

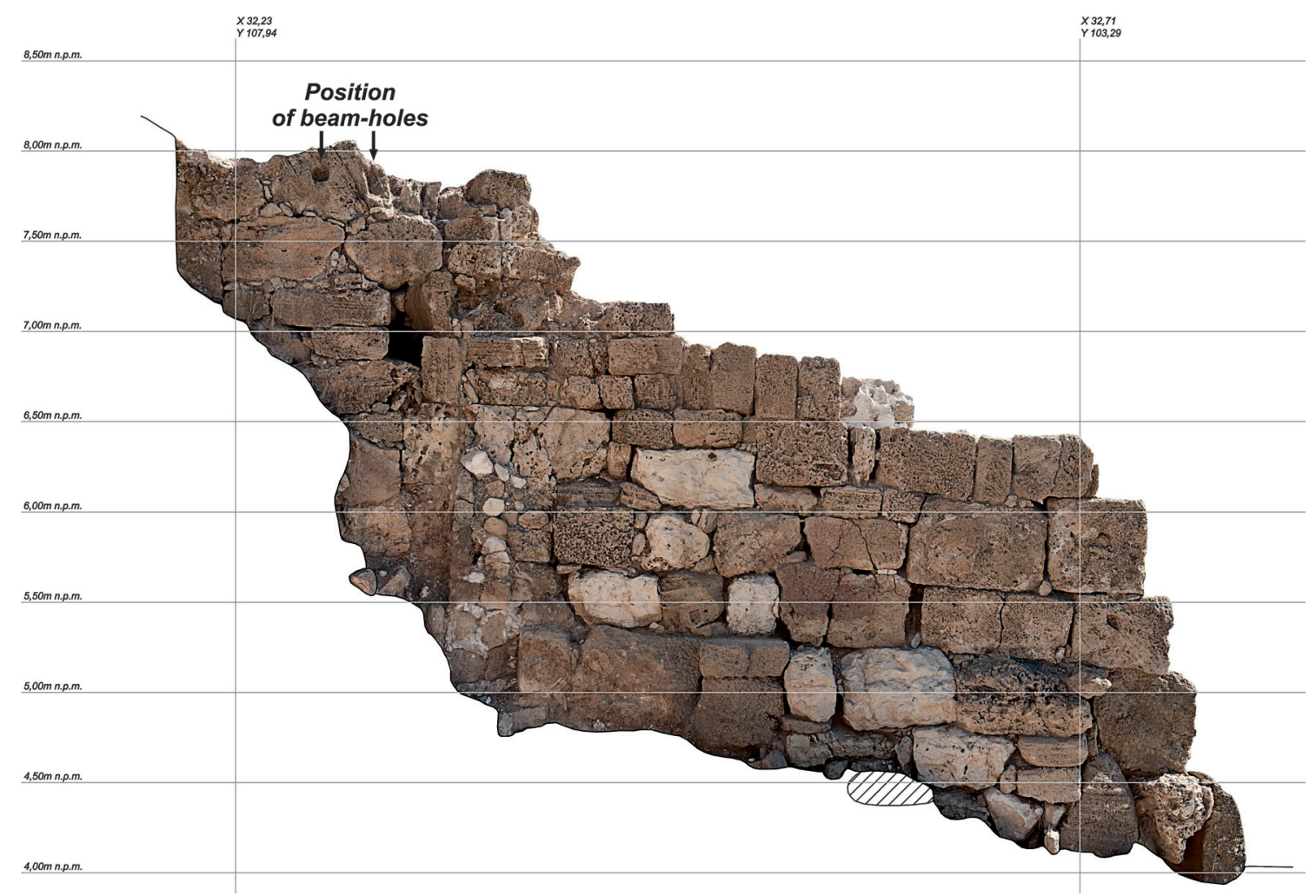

Fig. 9. East wall of room E1 (ortophoto R. Solecki)

with the street. D99 and D118, lying farther to the west, were marked in R. Saidah's plan as separate rooms, although no sign of a partition wall was observed in the explored part of the trench. There are, however, analogies from other parts of the site that make this assumption plausible. An entrance in the south wall of D118, which adjoins street D100, suggests that the room served as a vestibule in all likelihood. Rooms of this type are relatively small as a rule compared to neighboring chambers.
The sequence of two Early Byzantine floors in D96, also noted in test trenches in previous investigations in rooms D4 and D23, leads to the assumption that similar factors influenced the development of the entire northeastern part of the residential quarter in Sector D. Lack of evidence of destruction and refuse in the fill may indicate alterations taking place over a longer period of uninterrupted settlement. 


\section{SECTOR E ${ }^{14}$}

This sector lies about $30 \mathrm{~m}$ to the north of the western end of the Christian basilica (see Fig. 1). Buildings in this part of the site were constructed against a hill slope. Their southern part was seriously damaged probably in the $1980 \mathrm{~s}$. Clearing of modern accumulation revealed six rooms on the first floor and six on the upper story, the latter showing roughly the same layout as the former. The complex extended for about $8 \mathrm{~m}$ from east to west (Fig. 8). The height of the walls of the rooms on the ground level reached $3.50 \mathrm{~m}$, while the best preserved walls of the rooms on the second floor (in the eastern part of the building) were almost $1.40 \mathrm{~m}$ high.

Starting with the western end, room E6 on the first floor had the east wall cleared, consisting of the foundation huge chunks of sand conglomerate or bedrock, followed by two courses of blocks in opus isodomum and three in header-stretcher bond. Small part of the north wall was evidenced, interbonded with the east wall. A doorway in the east wall opened into room E1; it is now filled with rubble. A lime mortar floor in E1 was preserved only in the northwestern corner. An engaged pillar, interbonded with the west wall of the room, was extended in a later building event. The wall aligned $\mathrm{E}-\mathrm{W}$, which is now only $0.60 \mathrm{~m}$ high, was constructed of small ashlars of sand conglomerate. The preserved section is approximately $1.50 \mathrm{~m}$ long, but it must have once crossed the room, forming the northern border in this phase. The east wall of the room was built of roughly dressed blocks of sand conglomerate and limestone without regular coursing, set up on a $0.60 \mathrm{~m}$ wide footing and with sections of header-stretcher bond observed at the crown (Fig. 9). It could not be determined whether the wall structure was original or the effect of rebuilding. Room E7 to the north is now completely filled with collapsed walls and probably also the remains of the floor of the upper story.

Next in line to the east was room E2. It is poorly preserved, but retains three rows of stones of the same width as the room in the northern part, probably remains of stairs leading to the upper story (Fig. 10). This staircase was subsequently blocked by a wall surviving to a height of $1.50 \mathrm{~m}$. The corner of a platform under the upper floor standing in the northeastern part of this room makes the division between E2 and E3 farther to the east purely conjectural. The north wall of E3 is built of middle-sized ashlars, between which one noted large amounts of mortar mixed with small rubble and broken pottery. Nevertheless, it seems to be solid and built in one phase,

14 Excavations in this part of site were supervised by W. Hypiak and M. Mróz.

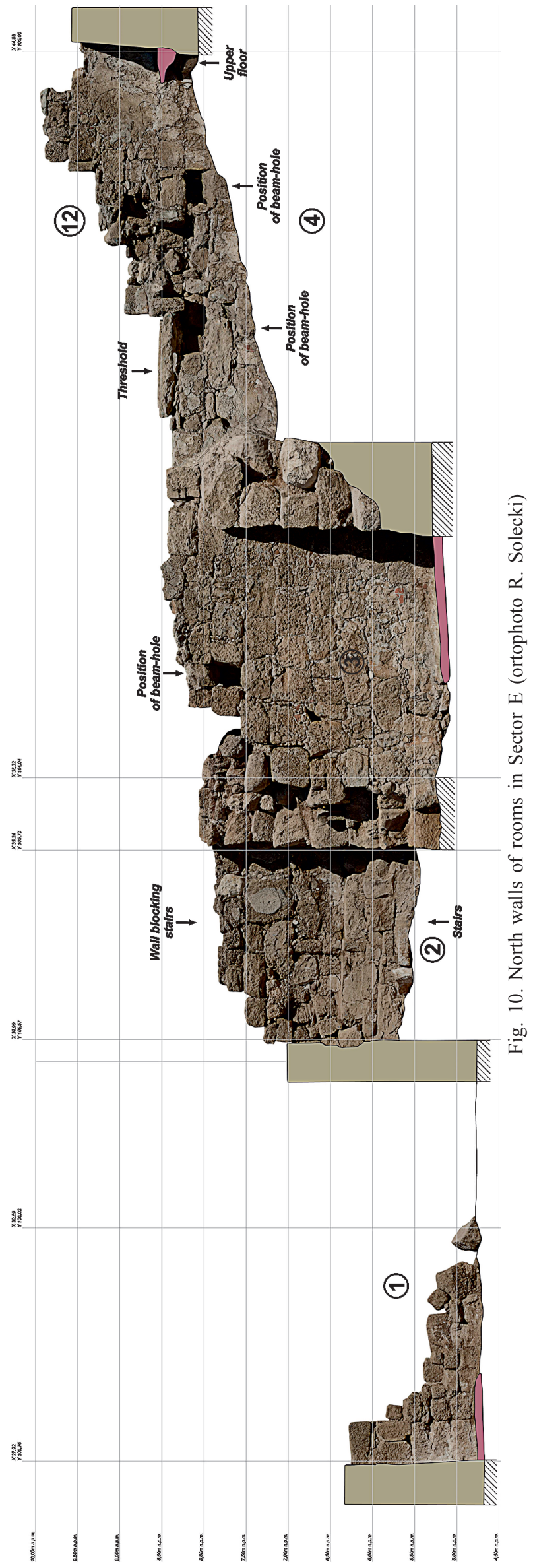




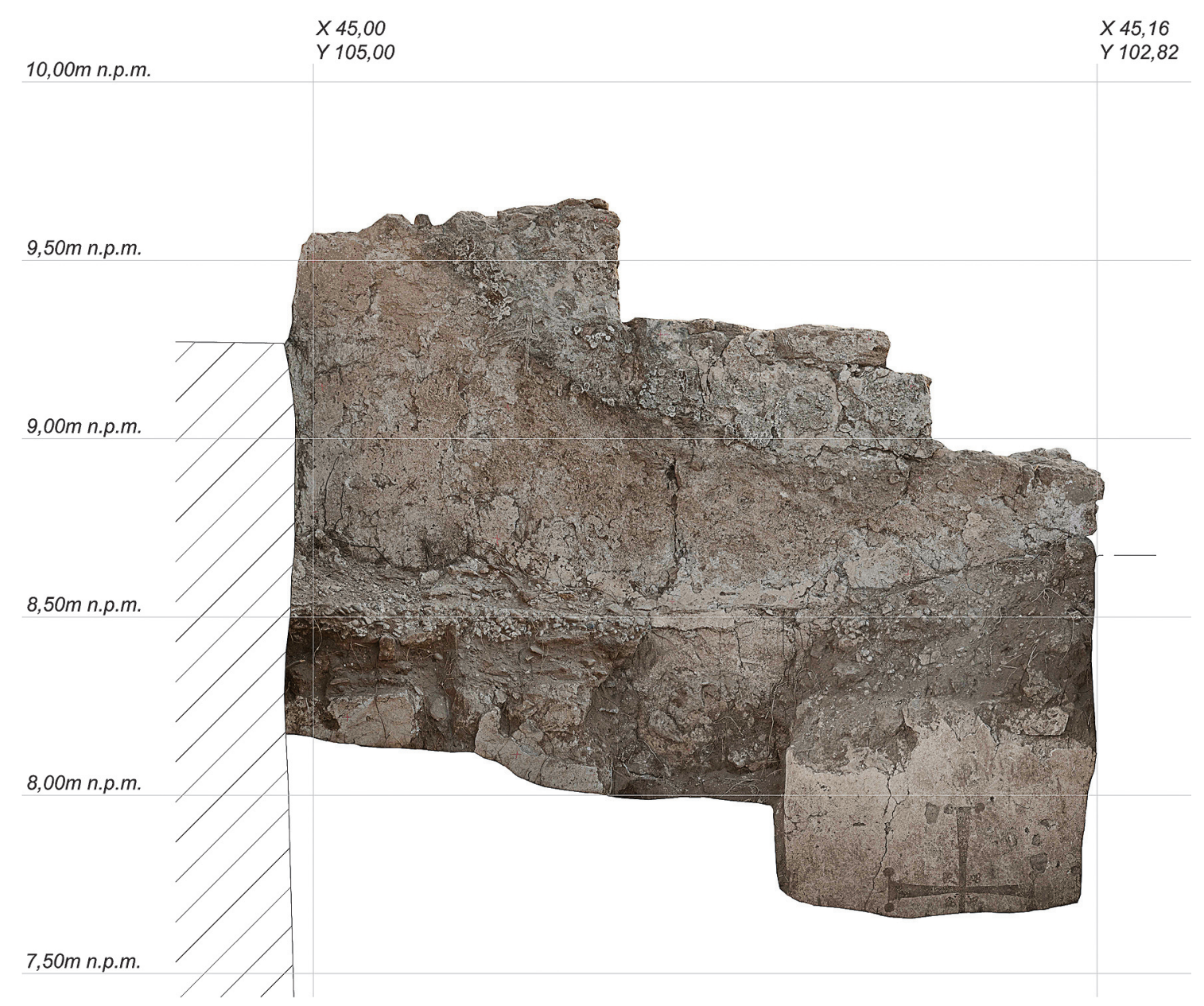

Fig. 11. Cross painted on a pilaster in room E4 and floor of upper-story room E12 (ortophoto R. Solecki)

with blocks in distinctively regular rows. The east wall of the room is significantly thicker than the rest and built using a different technique, with precisely fitting big blocks resembling opus emplectum. The joints between blocks were filled with large amounts of mortar and pottery fragments like in the north wall. Despite the different masonry techniques, the walls were interbonded demonstrating their contemporaneous construction. A floor of lime mortar was uncovered in the northeastern corner of this room.

The easternmost room in this line, E4, was not cleared down to the floor due to the accumulated thickness of the deposits. However, part of the face of the east wall was cleaned. The wall was plastered and reinforced in two places with engaged pilasters. The southern pilaster bore a large red-painted cross (Fig. 11). The horizontal arm measured $0.42 \mathrm{~m}$, but as the lower part of the cross was not wholly exposed, it cannot be determined whether it was of the Greek or Latin type. The mural was protected by backfilling with clean sand after being recorded. The north wall, with scant remains of plastering, was only fragmentarily cleared.
A socket in the east wall of E1, about $3 \mathrm{~m}$ above the occupational level, has been taken as proof of the existence of an upper-floor room (E10) (Fig. 9). It measured 9 by $8 \mathrm{~cm}$ and was used probably for fixing a wooden beam which supported the ceiling. Another partly preserved socket was noted $18 \mathrm{~cm}$ farther to the south, aligned with regard to the upper edge, but larger by $6 \mathrm{~cm}$ vertically. Cleaning of the crown of the wall revealed a mosaic in opus tesselatum made of multi-colored limestone and ceramic tesserae. Depicted on the floor was a lion walking to the left with raised tail; the paws are missing where the edge of the mosaic was destroyed (Fig. 12). The decorative border consisted of two rows of ceramic tesserae adjoining the fragmentarily preserved walls on the south and east. Assuming the representation was bigger, it could have extended only to the west and thus onto the presumed wooden ceiling (there are ashlar structures extant in the other directions). Significant quantities of colored mosaic fragments in opus tesselatum were found in the fill of room E7; they are interpreted as coming from the collapsed floor of the upper story. 
Farther to the east there was another room (E8) that was probably created after the blocking and filling of the staircase leading up from room E2. A wall roughly aligned on an E-W axis, preserved as one course of ashlars, bordered this space on the south. A floor of lime mortar was laid directly on the crown of the wall blocking the stairs, which should be associated with the creation of a new room (E9) above E2. Again, there are good reasons to think that the floor was suspended on a wooden substructure, but the east and west walls of room E2 were not preserved sufficiently high to show evidence of wooden-beam sockets.

The occupational level of room E5 rested on a platform of undressed blocks of limestone and sand conglomerate filling the space between the first floor walls in the southwestern corner. The floor bedding was made of small blocks of undressed sand conglomerate and the walls rose to a height of some 0.30-0.40 m. Room E5 continued to the east, but its precise layout cannot be determined pending the accumulated deposits in this area are cleared. The eastern continuation of the south wall of this room was best preserved, showing elements of headerstretcher bond at the crown recorded almost $1.40 \mathrm{~m}$ above the ceiling of the first floor.

A large socket about $0.30 \mathrm{~m}$ wide in the southern face of the north wall of E3, in which a wooden beam would have been fitted, attested to the presence of yet another room, E11, on the upper floor above E3 (see Figs 8 and 10). The bottom edge of this socket marks the height of room E3, which would have measured c. $2.80 \mathrm{~m}$.

The strongest evidence for a room located to the south of the eastern part of E5 and upstairs from E4 was a limestone threshold on the crown of the wall between E5 and E4, about $3.30 \mathrm{~m}$ above the floor level in room E3. Sockets in the stone indicate that the door opened to the south. A partly preserved floor of lime mortar adjoined the east wall over room E4. It was approximately $0.20 \mathrm{~m}$ thick and rested on two engaged pillars $0.25-0.30 \mathrm{~m}$ thick. Their tops roughly corresponded to the top edge of the wooden-beam sockets in the north wall of E4 (see Figs. 8 and 10). The western one was located directly below the threshold to E5 and had been damaged by the destruction of the wall in this place, but it was clearly about $0.20 \mathrm{~m}$ deep. The other socket, located to the east of the first one, was about $0.25 \mathrm{~m}$ deep, approximately $0.40 \mathrm{~m}$ wide and $0.20 \mathrm{~m}$ high. Planks or branches would have been placed across the two large beams mounted in these sockets, covered next with earth to make a bedding for a layer of undressed blocks of sand conglomerate and pebbles, and topped with a surface of lime mortar (see Fig. 11).

To recapitulate, at least 12 rooms, some of which were located on the upper story, were identified in

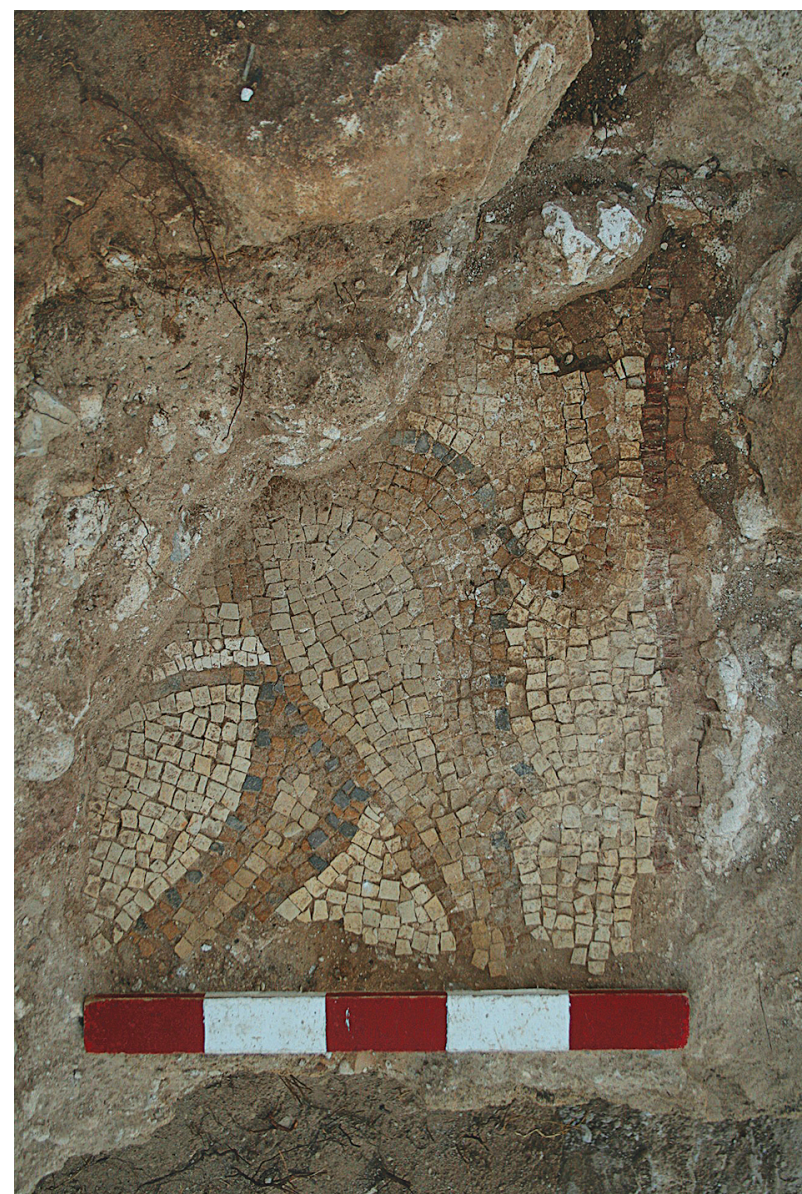

Fig. 12. Fragment of a mosaic floor with the representation of a lion from Sector E (photo M. Wyżgoł)

the building complex found in Sector E. The layout of the rooms and the figurative mosaic on the upper floor indicate that it was probably a big storied house. The coherence of the complex and the interconnected rooms suggest a single complex, although it should be noted that partial and complete blocking of some of the passages took place at one point. At that time, the house was probably divided into a few smaller ones. Regarding dating, fine-ware ceramics from Sector E were almost exclusively of Early Byzantine date (4th -7 th century). The painting representing a Christian cross found on one of the walls also indicates that the building was in use in the Early Byzantine period. The building techniques observed here were not significantly different from those attested in the other sectors of the site; moreover, there was no trace of structures from the earlier settlement phases such as in Sector D. ${ }^{15}$ All of this speaks in favor of dating the building complex in Sector E to the same period as the residential quarter in Sector D.

15 See WALISZEWSKI, JUCHNIEWICZ, GWIAZDA 2012: 431437. 


\section{DISCUSSION ${ }^{16}$}

The architectural evidence obtained during the investigations in 2012 and 2013 allows for more detailed observations which in turn may contribute to our better understanding of the history and character of the architecture and building techniques used in Early Byzantine Jiyeh. The following discussion, which focuses on various aspects of the local residential architecture, while additionally referring to examples from other Syro-Palestinian settlements, aims at the first provisional characteristic of the houses in Jiyeh (Porphyreon).

While excavating the mosaic in room D92, an irregular cluster of tesserae in its northeastern part was noticed. The tesserae in this cluster were discolored and darker than the remaining ones (Figs. 7 and 13), which points to the probable existence of a heating installation in this place. ${ }^{17}$ Given the lack of clear traces of char on the floor's and wall's surfaces, it was embers rather than live fire to constitute the source of heat. It is possible that a charcoal brazier made from lead or bronze was placed in this spot for a longer period of time. Such braziers were widely used on sea ships in the Greco-Roman period. Installations of this kind had poor chances of preservation in archaeological context on land since the material they were made of was usually reused after melting down. ${ }^{18}$ This practice is best attested by the finds of large Early Byzantine metal objects from Beirut, preserved in their entirety only in layers that formed as the result of disasters. ${ }^{19}$ In terms of quality and size they exceed considerably the finds from archaeological layers of different kind which contain chiefly rubbish and small items lost by their owners.

A closer investigation of the mosaic in room D92 revealed also that the diagonal layout of the tesserae is largely inconsistent. This can be observed in those sections of the mosaic where the rows of tesserae were laid sometimes along a northeastern axis, sometimes along a northwestern one (Fig. 13). ${ }^{20}$ By distinguishing the sections with a different layout of the tesserae we can observe that in the western part of the mosaic they are wider along the axis defined by

16 The authors wish to thank M. Dzik, R. Solecki, R. Bieńkowski, and M. Wyżgoł for discussions concerning various aspects of the history of the site.

17 Traces of possible heating installations in the form of dark discolorations were noticed also on the mosaic floor in the northwestern corner of D13, next to the northern wall of D25, and in the northeastern corner of D30.

18 GALILI, SHARVIT 1999: 167-171.

19 SAGHIEH 1996: 41.

20 A similar technique of laying tesserae was also observed in the mosaics in rooms D1, D12, D13, D24, D25, D38, D42, D45, D47, D52, D65, and D101. Much more inconsistent layout was recorded in D30 where tesserae were laid diagonally and crosswise. the western wall of the room, whereas in the eastern part they are wider along the axis defined approximately by the northern wall. It can be assumed that the workers started to lay the floor in the farthest part of the room looking from the entrance and proceeded towards the door. The northwestern corner of the room was most suitable for the mosaicists to start their work; after the beginning of the work, they proceeded towards the east, approximately until the middle of the room, changing several times the orientation of the layout of the tesserae and laying them in sections that occupied the whole width of the floor. While working in the other half of the room, the mosaicists changed the direction in which they moved, as indicated by the orientation of the sections of the mosaic perpendicularly to the previous ones. In this part it is difficult to determine whether the work proceeded towards the southern or the northern exit of the room. In the eastern part of the mosaic the sections are smaller than in the western part. The width of the sections varies while their length is about $0.30 \mathrm{~m}$ in all of the cases. This unit reappears in the sections in the western part of the mosaic where the shorter edges of the respective sections have the same or double dimensions.

The fact that the tesserae were laid in sections within the same floor was certainly connected with the speed at which the underlayment was becoming solid. The reach of the mosaicists' hands must have been taken into consideration while applying mortar; otherwise the workers would have had to step on the fresh mortar in order to reach the remote edges. As for the section with the darker tesserae in the northeastern part of room D92, the fact that it comprises portions of two distinct sections with different tesserae orientation indicates that the unusual coloring of this part of the mosaic is connected with the utilization phase of the floor, not its construction phase. This provides us with another argument for the presence of a heating installation in this place.

In Early Byzantine Jiyeh we witness the use of mosaics on a scale which finds no parallel in the earlier history of the settlement. Each of the houses excavated thus far had at least one mosaic floor. This is not surprising in the context of the increasing number of mosaics in Phoenicia in the 5th and 6th centuries, ${ }^{21}$ especially since the majority of the mosaics are very simple and undecorated. Despite the fact that analogous white mosaics are found relatively often on the Levantine coast, they appear chiefly in buildings connected with wine production or fish breeding. ${ }^{22}$ The use of mosaics in such contexts is

\footnotetext{
21 MERRONY 2013: 44.

22 ABU KHALAF et al. 2006: 69-71, fig. 28; AYALON 1979; TAL, TAXEL 2008: 47-51; TAXEL 2009: 57-58.
} 


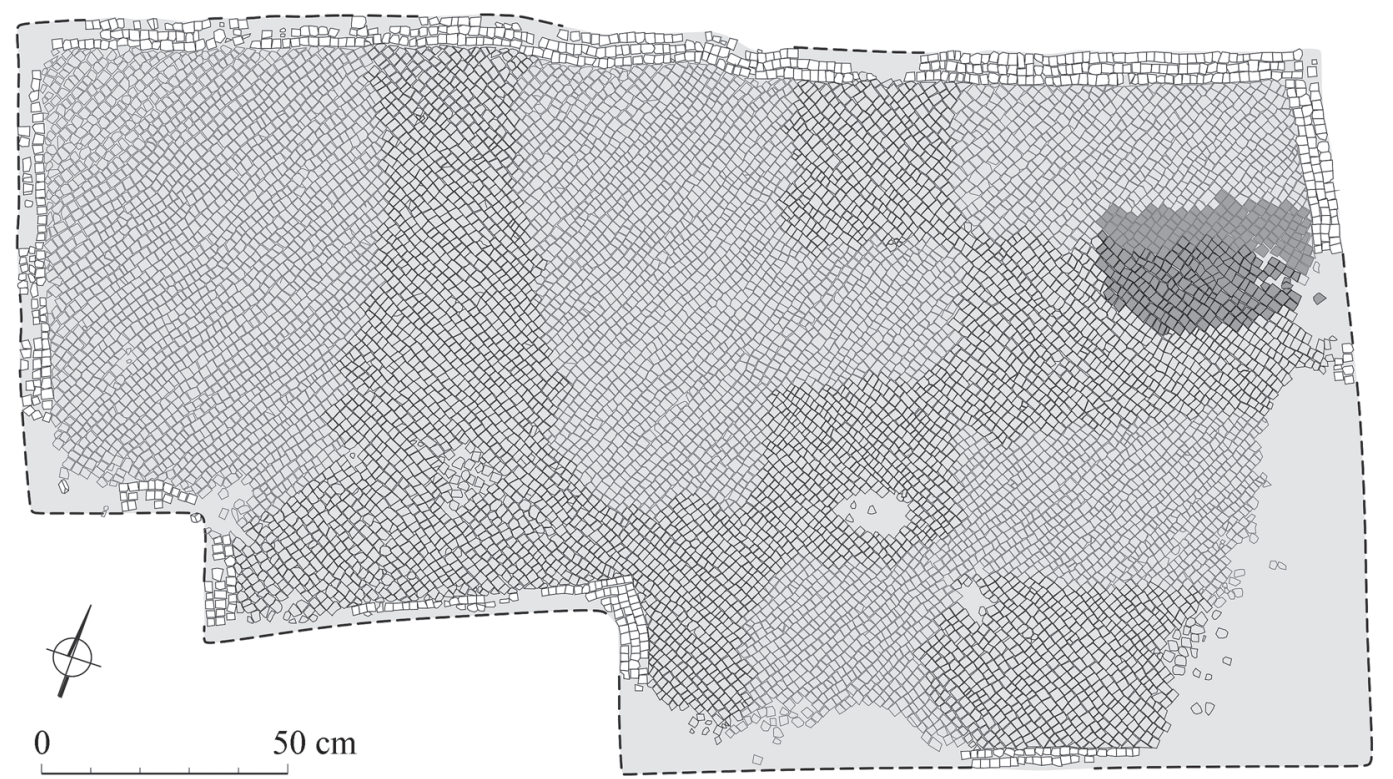

Fig. 13. Drawing of the mosaic floor in room D92 (drawing M. Gwiazda)

attested also in Jiyeh. In 2012, in the course of construction works, a complex of constructions connected most probably with wine production was discovered close to the southern border of the necropolis. The containers there were tiled with large white tesserae. ${ }^{23}$ On the other hand, until now such mosaics have been rarely discovered in residential buildings, for instance, in Early Byzantine houses in Tyre and Tell Jezreel. ${ }^{24}$

Four additional floor vessels were discovered during the 2012 and 2013 seasons. ${ }^{25}$ Examples of such installations are known from Early Byzantine houses in Tyre, where they were inserted in the middle of the rooms. ${ }^{26}$ They appeared also in Kfar Samir near Haifa and in the monastery at Khirbet Jemameh. ${ }^{27}$ Yet, they are attested not only in the settlements on the Levantine coast but also in the mainland, e.g. in en-Gedi on the Dead Sea coast. ${ }^{28}$ New discoveries from Jiyeh did not help to unravel the question of the function of these installations, but they allowed us to observe a certain regularity. Some of these installations are made of ceramic vessels, while others are made of cut blocks of sandstone conglomerate.

23 KOWARSKA, LENARCZYK 2015

24 DUVETTE 2012: 170; MOORHEAD 1997: 139, 143. Floors of this type are known also from the monastery at Khirbet Jemameh located $18 \mathrm{~km}$ east of Gaza, where they were found in many rooms that did not serve production or religious purposes (GOPHNA, FEIG 1993: 99, 100), as well as from Shiqmona in southern Phoenicia. However, in the latter case the character of the building where such a floor was discovered is unclear (HIRSCHFELD 2006: 133-134).

25 GWIAZDA 2012a.

26 DUVETTE 2012: 170.

27 FINKIELSZTEJN 2005: 447; GOPHNA, FEIG 1993: 100.

28 HIRSCHFELD 2005: 334-335, 344.
The finds of the latter type in rooms D42, D92, and D101 show that the second solution was applied in rooms with mosaic floors. ${ }^{29}$ Ceramic vessels, on the other hand, occur both with mortar and mosaic floors. We may wonder whether this regularity is connected with different functions of stone and ceramic containers. Thus far we lack convincing arguments to accept or reject such hypothesis.

The evidence from Sector E, including beam holes, as well as a fragment of the floor from the second story and the newly unearthed stairs in room D92 in Sector D, clearly point to the existence of multi-storied residential buildings in Early Byzantine Jiyeh. The diversity of methods of construction of ceilings can be discussed, based on various evidence uncovered chiefly in the course of the Polish-Lebanese excavations. The first method consisted in the use of a limited number of large beams, as observed in Sector E. The beams supported solid floors measuring c. $0.2 \mathrm{~m}$ in thickness. As yet, no evidence of such constructions has been discovered in the houses in Sector D. We cannot exclude, however, that this results from the state of preservation of architectural remains in this part of the settlement where walls rarely rise to more than 2 meters. Analogous ceiling constructions are known from multi-storied houses in Dehes and Serğilla in northern Syria. ${ }^{30}$

Another method of construction of ceilings and utilization levels in upper stories, observed at the site, consisted in the use of a large number of smaller wooden beams. Apart from Sector E, where the

\footnotetext{
29 See also WALISZEWSKI, GWIAZDA 2013: 330, fig. 10.

30 SODINI et al. 1980: 214-217, figs. 285-286; TATE et al. 2013: passim.
} 


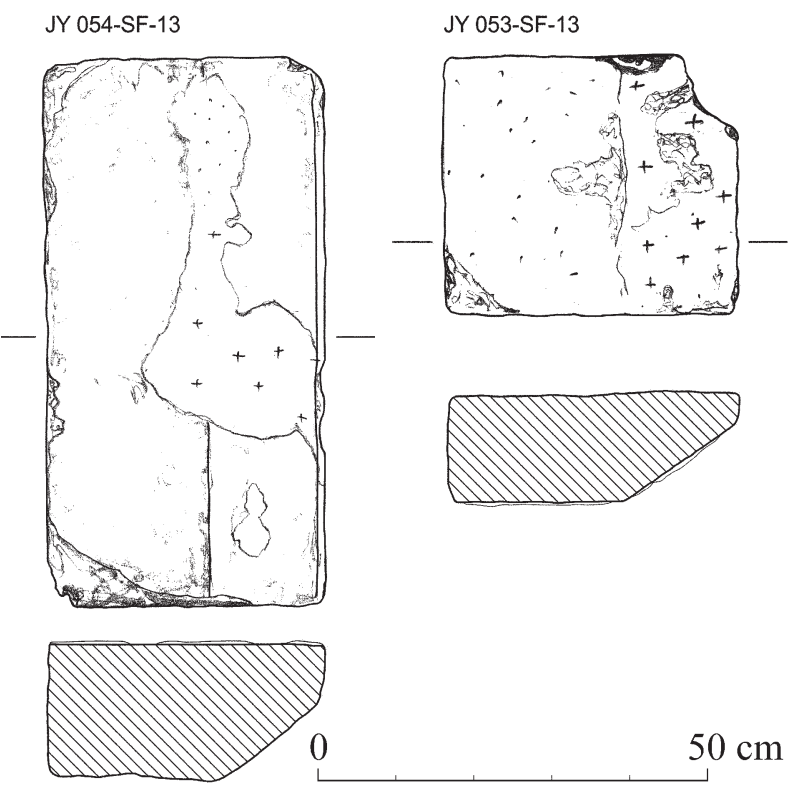

Fig. 14. Examples of beveled corbels found in Sector D (drawing M. Makowska, M. Gwiazda)

method was most probably applied in connection with mosaic floors, this type of ceiling construction is known also from Sector D and the Christian basilica. In Sector D it was applied in room D26, where in the northern wall seven rectangular holes could be observed disposed at intervals of c. $0.3-0.4 \mathrm{~m}$ and placed almost $2 \mathrm{~m}$ above the floor. The holes measured $0.08-0.18$ by $0.09-0.12 \mathrm{~m}$ and were $0.09-$ $0.15 \mathrm{~m}$ deep. Interestingly, no stone stairs leading to the upper story have been discovered in this house that consisted of at least three rooms (D48, D25 and D26). Therefore, we may speculate that in some cases the communication between the stories was achieved by means of wooden staircases. Several holes of this type were found also in the upper portions of the walls in rooms D15 and D18. Densely distributed holes are visible also on the archival photographs taken by R. Saidah in room D7. In the basilica, holes of this type were recorded in the eastern wall of the northern aisle, where we can assume the existence of an auxiliary room rather than a gallery. ${ }^{31}$

Wooden beams were used not only for constructing upper stories above the first floor of the buildings. In room D5, located east of street D8e, nothing was found on the level where we could expect the floor of the ground level. Below this level, the walls continued to a depth of $2 \mathrm{~m}$; numerous holes of different sizes visible in them indicate that in this case we are dealing with a cellar above which a floor was laid.

31 WALISZEWSKI et al. 2006: 30, fig. 38.
A similar cellar existed in a room located immediately to the south (D81). Here also holes for inserting the floor beams were found. ${ }^{32}$ Such type of construction is known from houses in Dehes and Serğilla. ${ }^{33}$

Finds of ten beveled corbels point to the use of yet another technique of ceiling construction. The corbels came exclusively from secondary fills connected mainly with the excavations of Roger Saidah, hence the impossibility to link these architectural elements to any of the excavated rooms. All examples are made of sandstone conglomerate plastered on the front side. One of the sides is always cut at an angle (Fig. 14). They are $0.13-0.18 \mathrm{~m}$ high and protrude $0.06-0.18 \mathrm{~m}$ beyond the face of the walls. Their part hidden in the structure of the wall measured $0.27-$ $0.40 \mathrm{~m}$; this does not exceed an average thickness of the walls in Sector D that measured no more than $0.5 \mathrm{~m}$. The lack of plaster on the corbels' sides indicates that these blocks were not used as consoles but formed cornices that ran along the walls. At present, we are unable to determine whether the cornices adorned all of the walls of a room or were placed solely on the opposite walls. Considering the relatively small number of these elements, the solution was probably not remarkably common. However, some of the corbels differ in respect of finishing and dimensions, which indicates that they were used in the construction of at least several ceilings in different rooms. Here it should be noted that such a method of ceiling construction is poorly attested in residential architecture of the Levantine coast. It was used chiefly in houses of the Syro-Palestinian interior. ${ }^{34}$

Another feature that should be taken into consideration while studying multi-storied residential architecture of Jiyeh is the use of pilasters that have better chances of preservation in the archaeological evidence than other elements of ceiling construction. Thus far, such pilasters are attested only in room E4, where they were used jointly with large wooden beams fixed in holes in the walls. Another example comes from Sector D where pilasters were found only in room D12. This room $(8 \times 3.7 \mathrm{~m})$ is the largest room excavated so far at the site. It has a mosaic floor and two pilasters measuring about $0.40-0.50 \mathrm{~m}$ in width, built in about two-thirds of the length of the east and west walls (Fig. 15). The pilasters and the walls with which they are connected are preserved to a height of no more than $1 \mathrm{~m}$ above the floor level. They certainly supported the ceiling of the room.

\footnotetext{
32 SAIDAH 1977: fig. 2.

33 SODINI et al. 1980: 132, figs. 59, 91, 96, 163; TATE et al. 2013: passim.

34 DAUPHIN, SCHONFIELD 1983: 197, pl. 22a; DE VRIES 2000: pl. 3, fig. 1; ClAuSS-BALTY 2008: 56-57; LENA 2008: 111-112.
} 
It appears that the majority of houses in Jiyeh were not covered with ceramic roof tiles; the relatively small number of roof tiles found at the site is to be connected mainly with the Early Byzantine basilica. This feature distinguishes the residential architecture of Jiyeh from that known from Beirut. In the latter case the use of this type of roofing is attested probably in the Hellenistic period and certainly in the Early Roman period. ${ }^{35}$ Tiles were used also in Early Byzantine houses in Tyre. ${ }^{36}$

Another element distinguishing the residential architecture of Jiyeh, excavated so far, from the residential architecture of the majority of Greco-Roman cities and villages of Syro-Palestine is the lack of peristyles, or courtyards. Instead of those, we find small vestibules that served chiefly communication purposes. In all cases such structures are connected with the street by a door. The major part of the vestibules had floors made from irregular slabs of limestone or sandstone conglomerate. In two cases in Sector D such rooms had mosaic floors (D61, D92). A vestibule gave access to at least two other rooms in the first floor of the houses. All of the stone staircases leading to upper stories, identified thus far, were located only in such spaces (D2, D15, D61, D71, and D92). Rooms of this type are usually the smallest in the houses, being approximately 9 sq.m. ${ }^{37}$ In comparison, in Sector D the average rooms with floors of lime mortar, usually located next to the vestibule, are 12.83 sq.m, ${ }^{38}$ while the average rooms with mosaics are 17.2 sq.m. ${ }^{39}$ This indicates that the discussed type of space did not serve as a courtyard, since large dimensions are one of the key characteristics of the latter. Another uniform feature of the courtyards, or portico courtyards, is lack of roofing. On the contrary, the vestibules in Jiyeh were certainly provided with ceilings, as indicated by the presence of waterspout draining the water from the roofs observed in the streets next to the entrances of these structures. Traces of such installations were unearthed next to

35 AUBERT 2001-2002: 77; MILLS 2013: 112-114.

36 DUVETTE 2012: 170

37 The calculations include rooms D2, D11, D15, D61, D71, D92 and D108B, together with the space occupied by staircases.

38 The calculations include rooms D3, D4, D7, D10, D14, D16, D17, D18, D19, D21, D22, D23, D26, D27, D28, D32, D33，D51，D53/D54，D55，D58，D60，D65，D66，D69，D70, D72, D74, D76, D102, D107 and D112. As in the case of the remaining calculations, the rooms with a floor of an uncertain type have not been included.

39 The calculations include rooms D1, D12, D13, D24, D25, D30, D38, D42, D45, D47, D52, D62, D63, D101, D108 and D109; we have not included the rooms in which stairs were found, as this feature makes them completely different from the remaining examples, neither the cases where the extent of the entire room was unknown (e.g., D94).

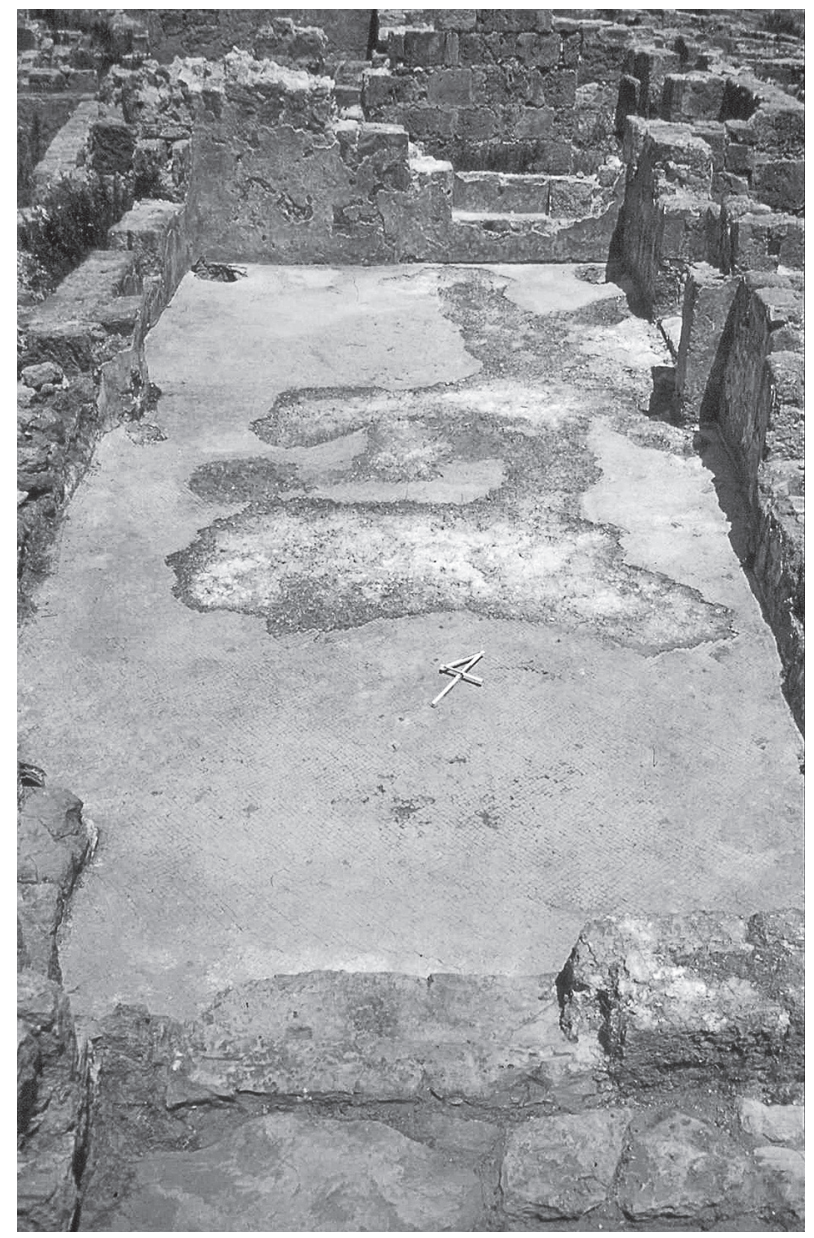

Fig. 15. Room D12, view from the south (photo T. Waliszewski)

vestibules D15, D2, D92, as well as in other rooms that were accessed directly from a street (D44, D46, D83, D85, and D108). On this basis we can draw a certain conclusion that the vestibules had roofs which gathered water from the remaining parts of the house; from there the water was finally piped into the drainage system of the village.

An exception to this rule is room D11, where the floor is made from stone slabs; the room gave access to two others. This space, closed with a door on the northern side, as indicated by the presence of a threshold, had a waterspout connected with a channel running under the main entrance, with an outlet leading to the public street. This shows that originally the room was not covered with a roof. However, at a certain moment the structure underwent a transformation. The change resulted from the blockage of the main entrance by the newly erected staircase leading to an upper story above D11.

The presence of such vestibules was observed also in Early Byzantine houses in Tyre. ${ }^{40}$ Moreover, houses

40 DUVETTE 2012: 170. 
without courtyards are known from the Early Byzantine residential architecture in Chhîm, a settlement located c. $6 \mathrm{~km}$ southeast of Jiyeh. In this village, flat roofs could have played a role of courtyards, which was certainly a result of the small size of the majority of the houses; however, neither in larger houses do we observe such structures. ${ }^{41}$

Given that a courtyard was - and remains till the present day - a constitutive element of traditional architecture in the Middle East, the lack of the house courtyards in Jiyeh and Chhîm raises questions about the reasons of such deviation from what appears to be a common practice. ${ }^{42}$ In our opinion, both settlements would have continued Phoenician architectural tradition going back at least to the Persian period. Such interpretation finds support in the discovery of a complex of 15 houses from the Persian period in Beirut; none of the buildings contained any space that could have played the role of a courtyard. ${ }^{43}$ Similarly, in Phoenician colonies in the Mediterranean we encounter houses without courtyards, while the presence of the courtyards in others is ascribed to Greek influences. ${ }^{44}$ However, the confirmation of this hypothesis requires a more thorough investigation of the houses in Jiyeh which predate the Early Byzantine phases of the settlement. Until now, Persian, Hellenistic, and Early Roman buildings have been investigated to a very modest extent. Nonetheless, the fact that the houses in Early Byzantine Chhîm largely date back to the Early Roman period when residential architecture also lacked such spaces, can be considered another premise to support the above conclusion.

The courtyards or peristyles are, on the other hand, well attested in Early Byzantine Beirut. This comes as no surprise, given the fact that Roman veterans settled in the city as early as the end of the 1st century BC. The first houses with courtyards are also dated to this period. ${ }^{45}$ However, the statement that the residential architecture of Jiyeh simply continued a pre-Roman tradition would be an oversimplification. The evidence from soundings in Sector D shows clearly the adoption of building techniques brought by Greek and Roman settlers. In the Persian period

41 See GALOR, WALISZEWSKI 2007: 13.

42 On Roman and Early Byzantine houses with courtyards, see HIRSCHFELD 1995.

4316 buildings were distinguished in a regular residential quarter from the Persian period. In only one of them the existence of a central courtyard with no roof is possible. This was, however, connected with a different character of this building which fulfilled the function of a temple (ELAYI, SAYEGH 2000: 155-167). On the lack of courtyards in Levantine houses in the Iron Age, see BRAEMER 1995: 100-101.

44 JimÉnEZ VialÁs, PRAdOS MARTínEZ 2013: 118-122.

45 PERRING 2007: 97-98. the basic technique of wall construction was the use of pillars made of ashlars, between which small fragments of broken rocks were placed. ${ }^{46}$ Since at least the 2nd century $\mathrm{BC}$, however, the settlement yields examples of opus isodomum. A similar transformation occurred also in Beirut in the same period. ${ }^{47}$ The common use of lime mortar in wall construction is, on the other hand, connected with the Early Roman period. The above observations show a great diversification of processes of acculturation in ancient Phoenicia. Such development did not mean a break with local traditions but was marked rather by the adoption of architectural solutions characterized by greater technological advancement. Local solutions, successfully fulfilling their role since many ages, were preserved in the process.

The lack of courtyards had a certain drawback, namely, the lack of daylight in the houses' interiors. The problem was solved not only by using artificial lighting. The evidence from the northeastern part of the residential quarter of Sector D indicates that windows were widely used for lighting the rooms. The windows recorded in the northern walls of rooms D13 and D14 and the southern wall of D4 were placed 2-3 $\mathrm{m}$ above the floor level, while those in the western wall of room D84 were placed much lower. They are seven in number and are distributed in three rows. The uppermost of the rows is c. $1.5 \mathrm{~m}$ above the floor level. ${ }^{48}$

All windows recorded in Sector D have a similar form: they are two or three times as high as they are wide and their size is modest. Their horizontal section is rectangular or trapezoidal; in the latter case the wider part is on the inside of the building. The modest size of the windows, their shape, and their placement high in the walls indicate that the lighting of the interior constituted their main function; probably they also served for ventilation which was necessary due to the presence of the aforementioned heating installations. However, the finds of window-panes in the Early Byzantine layers indicate that the latter functional aspect cannot be always taken into consideration. The overrepresentation of windows in the northeastern part of Sector D should be associated chiefly with the relatively good state of preservation of the walls adjoining the streets. Similar openings certainly existed on various heights also in the majority of the remaining houses in the settlement.

The presence of the openings in walls facing different cardinal directions indicates that the struggle for more light, even reflected, was intense as a con-

\footnotetext{
46 On this type of construction, see ELAYI 1996 (with further references).

47 AUBERT 2001-2002: 75-77.

48 See WALiSZEWSKI, GWIAZDA 2013: 327, fig. 6.
} 
sequence of densely built space. ${ }^{49}$ It should be noted that small windows in Jiyeh differ considerably from those known from rural houses in northern and southern Syria. In the latter case we encounter relatively large openings that frequently bear traces of mounting of wooden shutters. ${ }^{50}$ The presence of such windows is explained by the fact that the majority of them opened onto completely closed courtyards which allowed for safety and privacy. In Jiyeh these qualities were guaranteed by the use of small windows. We cannot exclude that the inhabitants of these houses gained privacy by arranging their private spaces in upper stories. However, we are still lacking evidence to prove such hypothesis.

The discovery of a layer of unmixed lime in room D112 (see above) shows that some of the rooms in the first floor could have been used as storerooms, especially since this new discovery is not an isolated case. The deposits of this kind or their negatives had been recorded in other rooms of Sector D excavated by R. Saidah. They were found in the southeastern half of room D31, northeastern corners of rooms D27, D22, and the southeastern part of D7. In all cases, the lime deposits were surrounded by low and narrow walls, which shows that separate spaces were arranged in the houses for storage purposes. Moreover, the fact that five different houses were provided with such deposits points to the independence of particular households and the significant role of lime in the residential architecture of Jiyeh. Probably, a major part of larger houses had reserves of this material which was used for current repairs of plastering and floors, possible rebuilding, or conservation of roofs. In one case, lime was stored in a room that was separated by another room from the vestibule of the house. In another case such a storeroom was located in a room next to the vestibule. In the remaining three cases the layout of the house is difficult to reconstruct due to the poor state of preservation of the walls.

This lack of a uniform pattern in the houses of Sector D is visible also in other aspects. As we have already mentioned while discussing the form of vestibules, the majority of examples had floors made of stone slabs; however, there are at least two departures from the rule where the floor was covered with a white undecorated mosaic. It was mostly the case that the vestibules had access to rooms with floors made of lime mortar (e.g., D71-D22-D70; D2-D3D4; D15-D14-D18; D48-D26), while the rooms

49 In Early Byzantine villages of the Limestone Massif in northern Syria there existed a practice of orientating the houses towards the south so that the largest possible amount of sunlight could reach their interiors (TATE 1992: 225).

50 TATE 1992: passim; BOPP 2006: passim; ClAUSS-BALTY 2008: 56; LENA 2008: 114. with mosaic floors were accessed through the latter. However, there are also rooms with mosaic floors that were accessed directly from the vestibule (e.g., D39-D38; D61-D62; D34-D12; D11-D12) or even directly from the street (e.g., D44, D47, D45, D63, D101, and D108), though they did not serve as a vestibule.

Another interpretational problem arises from the existence of upper stories in houses of both Sectors $\mathrm{D}$ and $\mathrm{E}$. The question is whether the plans of the houses which we know on the first floor level actually reflect separate residential complexes. The problem is exemplified by room D107: after the 2010 excavation season it seemed that after the blockage of all doorways the room ceased to be used.51 However, the discovery of room D92 in 2013, where a passage and a staircase were found, proved this interpretation wrong (see above). ${ }^{52}$ Studies of one of the Roman houses in Palmyra in Syria also raise serious objections as concerns conclusions about the layout of buildings based solely on the existence of passages between rooms on the first floor. Notwithstanding the lack of communication between two residential units on the first floor, there is evidence for a connection between these buildings on an upper level. ${ }^{53} \mathrm{We}$ also have to remember that independent residential complexes could emerge within particular houses as a result of property divisions between the members of a family; this could also lead to changes in the original function of certain rooms. ${ }^{54}$ All these elements show that at the present stage of research it is difficult to propose a general model of the layout of houses in the settlement. After unearthing more houses we will certainly be able to reconstruct not one, but several patterns reflecting the plans of the houses' constructors.

Simple generalizations are also undermined by the attestations of decorated mosaics with figural representations. Two such discoveries are known from residential buildings in Jiyeh. The first one comes from the area of modern fields between Sector D and the necropolis, where a mosaic with a Nilotic scene has been unearthed on the first-floor level of a building during the rescue excavations. ${ }^{55}$ The new discovery of the mosaic with a lion in Sector E proves that more expensive mosaic floors could exist in upper stories as well. However, we do not know whether these two rooms had the same function. In the former

51 WALISZEWSKI, GWIAZDA 2013: 325, fig. 3

52 On the northeastern residential quarter of Sector D, see also DZIK 2015, who gathers evidence for connections between the upper story rooms.

53 GAWLIKOWSKI 1997: 166.

54 See SALIOU 1992, for examples of houses in Dura Europos, with further references to the practice of house division.

55 ORTALI-TARAZI, WALISZEWSKI 2000. 
case we might be dealing with a reception room, while the latter room could have been part of private apartments. ${ }^{56}$ Another element that adds complexity to the picture are the finds of colorful tesserae made of stone or glass, as well as fragments of mosaics discovered in modern fillings from the cleaning of Sector D by R. Saidah, where no decorated floors have been discovered to date on first-floor levels, except for a mosaic with lilies from room D62.57 This may indicate that in this part of the site more elaborate floors would have existed in upper stories. ${ }^{58}$

Considering the discoveries of houses with figural mosaics in Jiyeh, we have to notice obvious differences in types of decoration encountered in rural residential architecture of other Early Byzantine sites in Syro-Palestine. Our site betrays the tendency to imitate the mosaic decoration of urban houses where geometric and figural motives were widely used, e.g. in Beirut. ${ }^{59}$ On the other hand, in northern and southern Syria, where the regional urban patterns were identical as in Phoenicia, the financial surpluses were not invested in such decorations. ${ }^{60}$ The houses of Syrian countryside are characterized chiefly by the abundance of architectural and relief decorations; the same is true also of the churches in the region. ${ }^{61}$

One of the factors that certainly contributed to this diversification consisted in different building materials available in these regions. Syria abounded in limestone and basalt that, contrary to sandstone conglomerate which was the basic building material on the Phoenician coast, allowed for the execution of complex stone decorations. Apart from mosaics, houses in Jiyeh were decorated with wall paintings, small fragments of which are found every year during the excavations. The majority of fragments are so small that we can only guess what they represented. Larger fragments feature floral and figural motifs. The majority of finds of this kind from Sector D bear inscriptions in Greek, or red crosses that in some cases could have had an apotropaic character. ${ }^{62}$

The settlement layout in Sector D seems to be in great measure a side effect of the layout of the houses. In the western part, practically all straight sections

56 On private triclinia in upper stories, see CLAUSS-BALTY 2008: 70 .

57 See SAIDAH 1977: 40.

58 Mosaics in upper stories of rural houses were found also in southern Phoenicia in Shiqmona (HIRSCHFELD 2006: 136). In the cities, floors of this kind connected with upper stories were discovered in Beirut (SAGHIEH 1996: 40).

59 SHEEHAN 1998: 155-165.

60 Isolated evidence of the presence of mosaic floors in upper stories of houses in the Limestone Massif come from Serğilla (TATE et al. 2013: 143, 195, 196).

61 SODINI et al. 1980; BOPP 2003: 51-52; DENTZER-FEYDY 2008: 184-209; NACCACHE 1992; STRUBE 1993; 2002.

62 See REY-COQUAIS 1982: 402. of the streets are very short and run parallel to the facades of irregularly shaped buildings. The layout of a large part of the houses is irregular. To a certain extent, this can be attributed to continuous rebuilding in the settlement during the Early Byzantine period. This is well exemplified by the newly unearthed rooms D97 and D117, as well as the small street D116, whose construction history is intertwined with the rebuilding of the neighboring basilica. ${ }^{63}$ The row of streets D8e-D115, which make up a fairly straight communication route almost $60 \mathrm{~m}$ long, seems to be an exception. However, this regularity is only apparent and does not bear testimony to unbound planning intentions of the builders. First, it seems that the form of the street is a function of the plans of the adjoining houses. On the eastern side, we notice irregularities which are the consequence of the fact that some of the eastern parcels either extend into the street or retreat from it. In the southern part of this section, where the newly excavated rooms are located, we observe a shift of the axis of street D115. Moreover, the form of this communication route was influenced by buildings from much earlier settlement phases, dated to the Persian and Hellenistic periods, like in the case of room D4, where the Early Byzantine walls next to the street were erected on top of walls laid in Phoenician bond. The situation is analogous in D23, where the Byzantine walls were again erected directly on much earlier walls of similar orientation. This was another factor that influenced the planning of the settlement and it cannot be overlooked in the attempts to reconstruct the ordering of space in the Early Byzantine village. ${ }^{64}$

Thus far, the excavated part of the settlement does not resemble at all the Syro-Palestinian cities with their long and wide streets. An argument for the existence of some forms of organization of the local community is provided rather by the construction of a complex system for drainage of rainwater that comprised Sector D almost in its entirety. The system was constructed probably towards the end of the 5 th century or already in the 6th century, thus sometime after the first Early Byzantine houses in this part of the site had been built. Its construction coincided more or less with the foundation of new floors in a number of the houses. Despite the fact that not all the sections of the drainage system are connected with the others, we can observe uniformity in their construction and the use of the same building techniques and materials. Moreover, in all cases the channels reach at least several houses, which indicates unquestionably that at a certain moment the inhabitants of this part of the settlement reached an agreement

63 See WALISZEWSKI et al. 2015.

64 See also WALISZEWSKI, GWIAZDA 2013: 331-332. 
about improving their living conditions, which entailed specific financial costs. The existence of drainage systems in introverted villages is not surprising; another example is the village of en-Gedi in Palestine. ${ }^{65}$

Thanks to the new stratigraphic soundings in several of the Early Byzantine rooms of Sector D and widening the older ones we are now able to obtain a more precise dating, which allows us to change the chronology of this part of the site. Moreover, in two cases we have gained evidence of a major rebuilding in the Early Byzantine period. In rooms D4 and D23 we observed a sequence of two floors dated to this period. The early phase of intensified building activity is dated to the late 4th or early 5 th century, following the years of less intense construction activity in the Roman period. The evidence supplements well the information obtained from the deposit of coins found in the wall of room D111 (see above) that can be dated to the second half of the 4th century. The late 5 th or the early 6th century constitutes the terminus a quo for the foundation of the subsequent utilization levels in D4 and D23. In D20 the last floor from the Early Byzantine period is dated to the second half of the 5th century or later. The conversions recorded so far in D4 and D23 do not find any clear justification in the archaeological evidence. The older floors seem to have been in a good state, although their surfaces were much worn. No evidence pointing to their sudden abandonment (which would have been connected with some kind of disaster) has been recorded immediately on them. These locations yielded no refuse layers; directly on these older floors there were deposits of uniform leveling layers used as a foundation for new floors. It is possible that the works attested by the presence of these new floors were connected with the construction of the aforementioned drainage system. The chronology, development and transformations of this part of the site are similar to what we can observe at the site BEY 006 in Beirut; here, like in Jiyeh, there was a decline in building activities in the 2nd and 3rd century, followed by a revival in the following centuries. ${ }^{66}$

The works conducted by the Polish-Lebanese mission since 1996 in Chhîm, a settlement which, like Jiyeh, was located in the territory of Sidon, give us the opportunity to compare examples of rural architecture from two different sites in the same administrative region of Phoenicia. Such comparison is necessary to determine the factors that influenced the appearance of the settlement in Jiyeh, as we cannot limit ourselves to analogies from the neighboring large cities such as Beirut or Tyre. The houses

\footnotetext{
65 HIRSCHFELD 2005: 353.

66 PERRING 2001-2002: 136-138; 2003: 211-213, 219; 2007: 101-103.
}

unearthed in Chhîm are dated mainly to the Roman and Byzantine periods. In spite of some similarities with the residential architecture of Jiyeh (e.g., the lack of courtyards or roofs covered with tiles) we observe at least several obvious differences. In Chhîm, one of the elements used in the construction of ceilings were vertical wooden beams set up on stone bases in the central part of a room. ${ }^{67}$ Finds of rollers used for conservation of the roofs were attributed to these upper levels. ${ }^{68}$ Thus far, these two elements have not been attested in Jiyeh. This points to the use of different techniques in the construction of ceilings/roofs at the two sites. Another difference consists in a different placement of staircases leading to upper stories. As already mentioned, in Jiyeh stairs were built in the vestibules. On the other hand, in Chhîm they were erected exclusively in public spaces, such as streets. ${ }^{69}$

The permanent furnishing of house interiors in Chhîm also seems to have been more diversified. Apart from niches in the walls used probably for storing everyday utensils, which have been found in both settlements, in Chhîm we observe the presence of benches next to the walls, as well as permanent kitchen stoves constructed in residential rooms. ${ }^{70}$ The two sites betray also significant differences in architectural details, such as thresholds at the houses' entrances. In Jiyeh we recognized a considerably larger number of their types than in Chhîm. ${ }^{71}$ Moreover, single-wing doors were preferred in Chhîm, whereas in Jiyeh the majority of doors had two wings. It is also clear that in Chhîm the produce of olive oil was tightly connected with the houses, as testified by several buildings that served both residential and economical functions. ${ }^{72}$ Other olive oil presses that functioned independently from residential spaces are located immediately nearby. ${ }^{73}$ So far, no traces of permanent installations associated with craft production or presses have been found in the houses of Sector D in Jiyeh. During excavations the

67 WALISZEWSKI 2001: 299, 303; 2002a: 247-248, 250; 2003 : 273; WALISZEWSKI, PÉRISSÉ 2005: 415-416; 2007: 417.

68 WALISZEWSKI 2002b: 15; WALISZEWSKI, PÉRISSÉ 2007: 420 .

69 WALISZEWSKI 2003: 274; 2004: 308-309.

70 On the benches, see WALISZEWSKI 2001: 303; 2002a: 248; WALISZEWSKI, PÉRISSÉ 2005: 415-416. On the kitchen stoves, see WALISZEWSKI 2000: 241; 2001: 303; 2002a: 245, 248; 2002b: 17-19; 2003: 273; WALISZEWSKI, PÉRISSÉ 2005: 412-413, 415-416). As shown by the evidence from D92, in Jiyeh the ovens were probably movable, though two kitchen stoves were also discovered in the settlement (WALISZEWSKI, GWIAZDA 2013: 328).

71 See GWIAZDA $2012 \mathrm{~b}$.

72 WALISZEWSKI 2000: 243; 2002a: 248-251; 2003: 275; 2004: 309-310.

73 WALISZEWSKI 2000: 238-239; 2014: 409-432; PÉRISSÉ, NORDIGUIAN 2002: 40. 


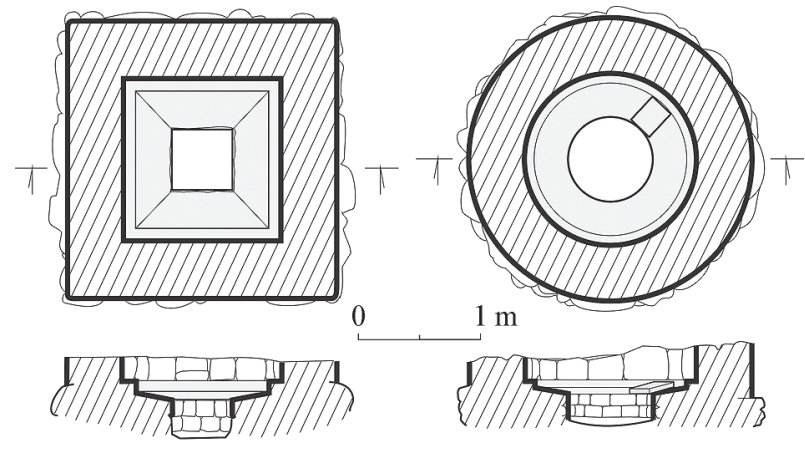

Fig. 16. Plans and sections of the elements of a wine press (drawing M. Puszkarski)

archaeologists found numerous remains testifying to local production in the settlement, but in none of the cases were they connected with the Early Byzantine houses. ${ }^{74}$ Remains of wine presses were found close to the northern boundary of the settlement in 2004 (Fig. 16) and during the rescue excavations in 2012. ${ }^{75}$ This might indicate that production activities in Jiyeh were in general pursued away from the inhabited area, similarly as in the Hellenistic and Roman periods when the industrial production was localized close to the border of the settlement, near the cemetery. ${ }^{76}$

\section{CONCLUSIONS}

The last two seasons of excavations yielded important evidence concerning the form, function and chronology of the Early Byzantine houses in Sector D in Jiyeh. On this evidence, we are able now to characterize more adequately the architecture of this part of the settlement. Differences between rural houses in Jiyeh and houses of the same kind in northern and southern Syria are obvious. In Syrian houses there are indications that rooms on the first floor served at least in part the purposes of animal husbandry and storage of agricultural products. Some of the buildings were also associated with installations for producing wine and olive oil. ${ }^{77}$ On the other hand, so far we found in Jiyeh no evidence for the houses having any function (like crafts, animal husbandry, or processing agricultural products) other than the residential and storing ones. Elements of a wine press unearthed close to the necropolis allow us to speculate that the areas of production were not connected with the residential quarters.

74 GWIAZDA 2014.

75 KOWARSKA, LENARCZYK 2015

76 DOMŻALSKI et al. 2005.

77 TATE 1997: 95-96, 99-100; BOPP 2006: 46, 63-70, 136; Clauss-BALTY 2008: 62-63; TATE et al. 2013: 143-145, see also EICHNER 2009: 88, 93.
Another obvious difference between the rural houses of Phoenicia and those in other parts of Syro-Palestine in the Early Byzantine period consists in the lack of courtyards in Phoenician houses, as exemplified by the evidence from Jiyeh and Chhîm. This can probably be connected with a continuation of the traditions of residential architecture of Phoenicia which predate the Greco-Roman period. Such interpretation is supported, among others, by the lack of courtyards in the houses from the Persian period unearthed in Beirut.

The coastal complex of houses excavated in Jiyeh differs in several aspects from the one known from Chhîm, a village located in the nearby mountains. The differences occur despite the fact that both villages were located in the chora of Sidon, which apparently should have greatly influenced the uniformity of material culture of the region. This, however, is true only to a limited extent. Other factors seem to have played a more crucial role: wealth differences between the inhabitants of the two settlements, available building materials, topography, or a different settlement history. Another key factor consists in the role of the two settlements in the local economic system. The village of Chhîm seems to have based on agricultural production, which is reflected in a relatively large number of installations connected with production of olive oil and wine; some of these installations were integrated with the houses. The raison d'etre of Jiyeh was more complex, including the processing of agricultural products and craftsmanship; the settlement could also play an important role in commercial exchange between the cities on the coast and mountain villages located to the east. ${ }^{78}$ Such economical differentiation certainly influenced the process of shaping the social structures and customs of everyday life, which in turn were reflected in material culture, in this case in the residential architecture.

\section{Mariusz Gwiazda}

Antiquity of Southeastern Europe Research Centre,

University of Warsaw

Krakowskie Przedmieście 32

PL - 00-325 Warszawa

Tomasz Waliszewski

Polish Centre of Mediterranean Archaeology,

University of Warsaw

Nowy Świat 4

PL - 00-492 Warszawa

\footnotetext{
78 See GWIAZDA 2014.
} 


\section{REFERENCES}

Abou Diwan, G. 2014. "À propos de l'usage de l'ère sidonienne à Porphyréôn (Jiyeh et Nabi Younès) à l'époque protobyzantine," Chronos 30, 145-163.

Abu Khalaf, M., I. Abu A'mar, S. Al-Houdalieh, and R. Hoyland. 2006. "The Byzantine and Early Islamic Settlement of Khirbat Shuwayka," Web Journal on Cultural Patrimony 1(2), Retrieved from http://www.webjournal.unior.it/Dati/18/55/3. Palestina, Abu Khalaf.pdf (accessed: February 2015).

Aubert, C. 2001-2002. "Architecture et décor de la maison hellénistique à Beyrouth," ARAM Periodical 13, 73-85.

Ayalon, E. 1979. "The Jar Installation of Khirbet Sabiya," Israel Exploration Journal 29(3/4), 175-181.

Bopp, E.M. 2003. "Die Bauornamentik in den antiken Wohnhäusern des Hauran," in: K.S. Freyberger, A. Henning, and H. von Hesberg (eds.), Kulturkonflikte im Vorderen Orient an der Wende vom Hellenismus zur römischen Kaiserzeit (OrientArchäologie 11), Rahden, 47-63.

Bopp, E.M. 2006. Die antike Wohnkultur des Hauran in Syrien (Orient-Archäologie 19). Rahden.

Braemer, F. 1995. "Habitat et architecture domestique dans le Levant des âges des métaux. Quelques orientations de la recherche des dix dernières années," Topoi 5(1), 89-110.

Clauss-Balty, P. 2008. "Maisons romano-byzantines dans les villages de Batanée: missions 2002-2004," in: P. Clauss-Balty (ed.), Hauran III. L'habitat dans les campagnes de Syrie du sud aux époques classique et médiévale (Bibliothèque archéologique et historique 181), Beirut, 41-104.

Dauphin, C. M. and J.J. Schonfield. 1983. "Settlements of the Roman and Byzantine Periods on the Golan Heights: Preliminary Report on Three Seasons of Survey (1979-1981)," ISrael Exploration Journal 33(3/4), 189-206.

Dentzer-Feydy, J. 2008. "Les décor architectural des maisons de Batanée," in: P. Clauss-Balty (ed.), Hauran III. L'habitat dans les campagnes de Syrie du sud aux époques classique et médiévale (Bibliothèque archéologique et historique 181), Beirut, $183-232$.

de Vries, B. 2000. "Continuity and Change in the Urban Character of the Southern Hauran from the 5th to the 9th Century: The Archaeological Evidence at Umm al-Jimal," Mediterranean Archaeology 13, 39-45.

Domżalski, K., U. Wicenciak, M. el-Tayeb, and T. Waliszewski. 2005. "Late Hellenistic and Early Roman Pottery Production Center at Jiyeh. Rescue Excavations 2004," PAM 16, 429-439.

Duvette, C. 2012. "Le secteur 7, un quartier d'habitat au pied du complexe thermal de Tyr," in: A.-M. Maïla-Afeiche (ed.), L'histoire de Tyr au témoignage de l'archéologie: actes du séminaire international, Tyr 2011 (Bulletin d'archéologie et d'architecture libanaises, Hors-Série 8), Beirut, 157-176.

Dzik, M. 2015. "Preliminary Results from Stratigraphic Analysis of Late Roman and Early Byzantine Architecture of the Residential Quarter in Jiyeh,” PAM 24/1, 487-502.

Eichner, I. 2009. "Ländliche Häuser der spätantik-frühbyzantinischen Zeit in Syrien und Kilikien," in: I. Eichner and V. Tsamakda (eds.), Syrien und seine Nachbarn von der Spätantike bis in die islamische Zeit, Wiesbaden, 81-101.

Elayi, J. 1996. "Nouveaux éléments sur le mur à piliers phénicien," Transeuphratène 11, 77-94.

Elayi, J. and H. Sayegh. 2000. Un quartier du port phénicien de Beyrouth au fer III/Perse: Archéologie et histoire (Transeuphratène Supplément 7), Paris.

Finkielsztejn, G. 2005. "Les mosaïques de la komopolis de Porphyreon du sud (Kfar Samir; Haïfa, Israël): Un évêché (?) entre village et cité," in: H. Morlier (ed.), La mosaïque gréco-romaine IX: Actes du IXe Colloque international pour l'étude de la mosaïque antique et médiévale organisé à Rome, 5-10 novembre 2001, Vol. 1 (Collection de l'École française de Rome 352), Rome, 435-452.

Galili, E. and J. Sharvit. 1999. "Ship Fittings and Devices Used by Ancient Mariners: Finds from Underwater Survey off the Israel Coast," in: H. Tzalas (ed.), 5th International Symposium on Ship Construction in Antiquity, Nauplia, 26, 27, 28 August 1993: Proceedings, Athens, 167-183.

Galor, K. and T. Waliszewski. 2007. "Introducing 'From Antioch to Alexandria' or Why Write about Domestic Architecture in the Greco-Roman Near East," in: K. Galor and T. Waliszewski (eds.), From Antioch to Alexandria: Recent Studies in Domestic Architecture, Warsaw, 7-24.

Gawlikowski, M. 1997. "L'habitat à Palmyre de l'antiquité au Moyen-Age," in: C. Castel, M. al-Maqdissi, and F. Villeneuve (eds.), Les maisons dans la Syrie antique du III ${ }^{e}$ millénaire aux débuts de l'Islam: pratiques et représentations de l'espace domestique. Actes du colloque international, Damas, 2730 juin 1992 (Bibliothèque archéologique et historique 150), Beirut, 161-166.

Gophna, R. and N. Feig. 1993. "A Byzantine Monastery at Kh. Jemameh," 'Atiqot 22, 97-108.

Gwiazda, M. 2012a. "Sunken Vessels in Late Roman and Byzantine Houses in Area D, appendix to: T. Waliszewski, K. Juchniewicz, and M. Gwiazda, Preliminary Report on the 2008 and 2009 Excavation Seasons at Jiyeh (Porphyreon)," PAM 21, 439-440.

Gwiazda, M. 2012b. "Preliminary Remarks on Thresholds from Private Houses in Jiyeh (Porphyreon), appendix to: T. Waliszewski, K. Juchniewicz, and M. Gwiazda, Preliminary Report on the 2008 and 2009 Excavation Seasons at Jiyeh (Porphyreon)," PAM 21, 441-443.

Gwiazda, M. 2014. "Economy of Hellenistic, Roman and Early Byzantine settlement in Jiyeh (Porphyreon), Lebanon," Archeologia 62-63, 2011-2012, 31-44.

Hirschfeld, Y. 1995. The Palestinian Dwelling in the Roman-Byzantine Period (Studium Biblicum Franciscanum. Collectio minor 34), Jerusalem.

Hirschfeld, Y. 2005. "En-Gedi: 'a very large village of Jews'," Liber Annuus 55, 327-354.

Hirschfeld, Y. 2006. "Excavations at Shiqmona - 1994," 'Atiqot 51, $131-143$.

Jiménez Vialás, H. and F. Prados Martínez. 2013. "Espacio doméstico y estructura social en contextos púnicos," in: S. Gutiérrez lloret and I. Grau Mira (eds.), De la estructura doméstica al espacio social: lecturas arqueológicas del uso social del espacio, San Vicente del Raspeig, 111-126.

Kowarska, Z. and S. Lenarczyk. 2015. "Results of a Survey Conducted in the Area of the Jiyeh Marina Resort Hotel Complex in the 2012 Season," PAM 24/1, 503-515.

Lena, É. 2008. "Le Dar Majarish à Muhajat. Dispositifs spatiaux, systèmes constructifs: une étude de cas," in: P. Clauss-Balty (ed.), Hauran III. L'habitat dans les campagnes de Syrie du sud aux époques classique et médiévale (Bibliothèque archéologique et historique 181), Beirut, 105-134.

Merrony, M.W. 2013. Socio-Economic Aspects of Late Roman Mosaic Pavements in Phoenicia and Northern Palestine (British Archeological Reports. International Series 2530), Oxford.

Mills, P. 2013. The Ancient Mediterranean Trade in Ceramic Building Materials: A Case Study in Carthage and Beirut (Roman and Late Antique Mediterranean Pottery 2), Oxford.

Moorhead, T.S.N. 1997. "The Late Roman, Byzantine and Umayyad Periods at Tel Jezreel," Tel Aviv 24(1), 129-166. 
Naccache, A. 1992. Le décor des églises de villages d'Antiochène $d u V^{e}$ au VII ${ }^{e}$ siècle (Bibliothèque archéologique et historique 144), Paris.

Ortali-Tarazi, R. and T. Waliszewski. 2000. "La mosaïque du Nil découvert à Jiyé," Bulletin d'archéologie et d'architecture libanaises 4, 165-177.

Périssé, I. and L. Nordiguian. 2002. "Sanctuaire romain," in: T. Waliszewski and R. Ortali-Tarazi, "Village romain et byzantin à Chhîm-Marjiyat. Rapport préliminaire (1996-2002)," Bulletin d'archéologie et d'architecture libanaises 6, 29-41.

Perring, D. 2001-2002. "Beirut in Antiquity: Some Research Directions Suggested by Recent Excavations in the Souks," ARAM Periodical 13, 129-140.

Perring, D. 2003. "The Archaeology of Beirut: a Report on Work in the Insula of the House of the Fountains," Antiquaries Journal 83, 195-229.

Perring, D. 2007. "The Roman and Byzantine Houses of Beirut," in: K. Galor and T. Waliszewski (eds.), From Antioch to Alexandria: Recent Studies in Domestic Architecture, Warsaw, 95-105.

Rey-Coquais, J.-P. 1982. "Inscriptions grecques inédites, découvertes par Roger Saidah," in: Archéologie au Levant: recueil à la mémoire de Roger Saidah (Collection de la Maison de l'Orient méditerranéen 12), Lyon, 395-408.

Saghieh, M. 1996. "BEY 001 and 004 Preliminary Report," Bulletin d'archéologie et d'architecture libanaises 1, 23-59.

Saidah, R. 1977. "Porphyréon du Liban: une Pompéi byzantine enfouie sous le sable," Archéologia 104, 38-43.

Saliou, C. 1992. "Les quatre fils de Polémocratès (P. Dura 19). Texte et archéologie," Syria 69(1), 65-100.

Sheehan, P. 1998. "Mosaics from BEY 006: an Introductory Catalogue," Berytus 43, 147-166.

Sodini, J.-P., G. Tate, B. Bavant, S. Bavant, J.-L. Biscop, D. Orssaud, C. Morrisson, and F. Poplin. 1980. "Première partie: Étude archéologique des bâtiments 101 à 108," Syria 57(1), $11-181$.

Strube, C. 1993. Baudekoration im nordsyrischen Kalksteinmassiv I. Kapitell-, Tür- und Gesimsformen der Kirchen des 4. und 5. Jahrhunderts n. Chr (Damaszener Forschungen 5), Mainz am Rhein.

Strube, C. 2002. Baudekoration im nordsyrischen Kalksteinmassiv II. Das 6. und frühe 7. Jahrhundert (Damaszener Forschungen 11), Mainz am Rhein.

Tal, O. and I. Taxel. 2008. Ramla (South): An Early Islamic Industrial Site and Remains of Previous Periods (Salvage Excavation Reports 5), Tel Aviv.

Tate, G. 1992. Les campagnes de la Syrie du Nord du II au VII siècle: un exemple d'expansion démographique et économique dans les campagnes à la fin de l'antiquité (Bibliothèque archéologique et historique 133), Paris.

Tate, G. 1997. "La maison rurale en Syrie du Nord," in: C. Castel, M. al-Maqdissi, and F. Villeneuve (eds.), Les maisons dans la Syrie antique du III millénaire aux débuts de l'Islam: pratiques et représentations de l'espace domestique. Actes du colloque international, Damas, 27-30 juin 1992 (Bibliothèque archéologique et historique 150), Beirut, 95-101.

Tate, G., M. Abdulkarim, G. Charpentier, C. Duvette, and C. Piaton. 2013. Serğilla, village d'Apamène I. Une architecture de pierre (Bibliothèque archéologique et historique 203), Beirut, 95-101.

Taxel, I. 2009. Khirbet es-Suyyagh: A Byzantine Monastery in the Judaean Shephelah (Salvage Excavation Reports 6), Tel Aviv.

Waliszewski, T. 2000. "Chhîm. Explorations, 1999," PAM 11, 237-245.

Waliszewski, T. 2001. “Chhîm. Explorations, 2000,” PAM 12, 297-306.

Waliszewski, T. 2002a. "Chhîm. Explorations, 2001," PAM 13, $243-253$.

Waliszewski, T. 2002b. "Village," in: T. Waliszewski and R. Ortali-Tarazi, "Village romain et byzantin à Chhîm-Marjiyat. Rapport préliminaire (1996-2002)," Bulletin d'archéologie et d'architecture libanaises 6, 15-21.

Waliszewski, T. 2003. "Chhîm. Explorations, 2002," PAM 14, $265-275$

Waliszewski, T. 2004. "Chhîm. Explorations, 2003," PAM 15, 303-310.

Waliszewski, T. 2014. Elaion: Olive Oil Production in Roman and Byzantine Syria-Palestine (PAM Monograph Series 6), Warsaw.

Waliszewski, T., M. Antos, P. Jaworski, P. Makowski, M. Romaniuk, R. Solecki, and A. Szymczak. 2015. "Preliminary Report on the 2012 and 2013 Excavation Seasons at Jiyeh (Porphyreon): Work in Sector D (Residential Quarter)," PAM 24/1, 465-485.

Waliszewski, T. and M. Gwiazda. 2013. "Preliminary Report on the 2010 Excavation Season at Jiyeh (Porphyreon)," PAM 22, $321-333$.

Waliszewski, T. and M. Gwiazda. 2015. "Porphyreon through the Ages: The Fading Archaeological Heritage of the Lebanese Coast," Journal of Eastern Mediterranean Archaeology \& Heritage Studies 3(4), 330 - 348.

Waliszewski, T., K. Juchniewicz, and M. Gwiazda. 2012. "Preliminary Report on the 2008 and 2009 Excavation Seasons at Jiyeh (Porphyreon)," PAM 21, 423-445.

Waliszewski, T. and I. Périssé. 2005. "Chhîm. Explorations 2004," PAM 16, 411-418.

Waliszewski, T. and I. Périssé. 2007. "Chhîm. Explorations 2005," PAM 17, 411-420.

Waliszewski, T., U. Wicenciak, M. El Tayeb, K. Domżalski, A. Witecka, M. Wagner, T. Herbich, I. Noureddine, M. Woźniak, K. Kotlewski, and R. Żukowski. 2006. "Jiyeh (Porphyreon): Hellenistic, Roman and Byzantine settlement on the southern coast of Lebanon. Preliminary report on the 1997 and 20032005 seasons," Bulletin d'archéologie et d'architecture libanaises $10,5-84$.

Waliszewski, T. and U. Wicenciak. 2015. "Jiyeh (Porphyreon). Nouvelles découvertes sur le territoire de Sidon à l'époque hellénistique," Topoi Supplément 13, 155-179. 